\title{
Bank Globalization and Monetary Policy Transmission in Small Open Economies
}

\author{
Inhwan So*
}

The views expressed herein are those of the author and do not necessarily reflect the official views of the Bank of Korea. When reporting or citing this paper, the author's name should al ways be explicitly stated.

* International Department, The Bank of Korea, Tel: +82-2-759-5993 E-mail: ihsoh@bok.or.kr.

The last version of the paper was completed while the author was at the Economic Research Institute, the Bank of Korea. The author is grateful for valuable comments from Yu-chin Chen, Fabio Ghironi, Ji Hyung Lee, Jongrim Ha, Byung Kwun Ahn, Byungkuk Kim, Hyung Chang Yi, Anthony Landry and seminar participants at the University of Washington, the Bank of Korea, 2017 Annual Meeting of the Central Bank Research Association and 2017 China Meeting of Econometric Society. 


\section{Contents}

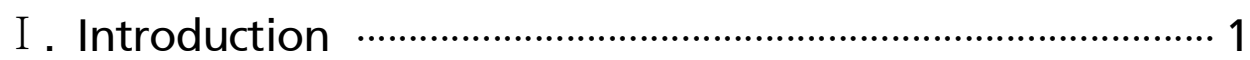

II. Vector Autoregressive (VAR) Analysis ……………….... 6

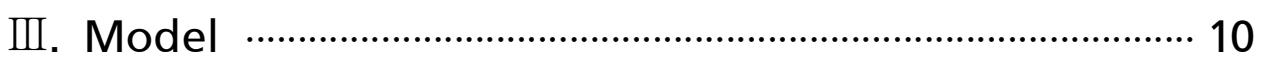

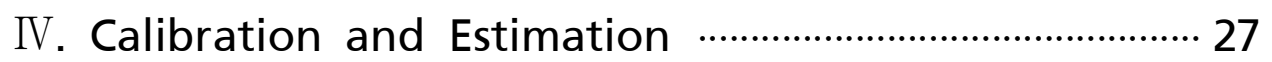

V. The Transmission Mechanism of MP Shocks ……..... 32

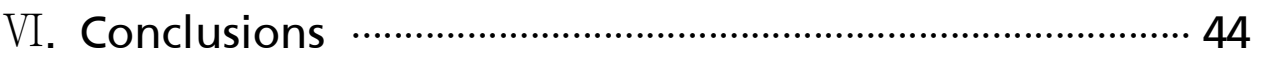

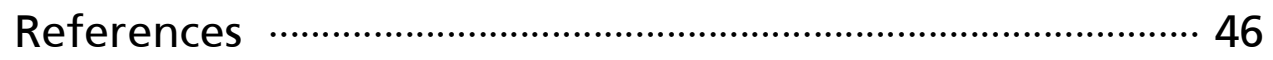

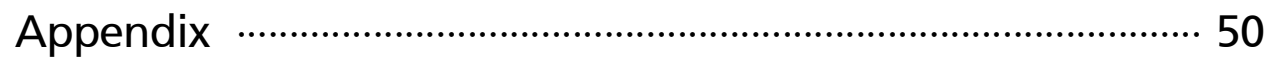




\section{Bank Globalization and Monetary Policy Transmission in Small Open Economies}

This paper investigates how the openness of banking sector influences the transmission channels of home and foreign monetary policy shocks in small open economies. For the analysis, I construct a small open economy DSGE model enriched with a banking sector. I consider two forms of bank globalization: international bank capital finance and foreign loan account import. From the analysis, I find that bank globalization leads to a significant attenuation of domestic monetary policy transmission. On the other hand, opening of the banking sector intensifies the impact of foreign interest rate shocks on the local bank activities.

Keywords: Bank globalization, Monetary policy, Dynamic stochastic general equilibrium model, Small open economies

JEL Classification Numbers: E32, E44, E52, E58, F36, F62 


\section{I . Introduction}

This paper examines how the openness of the financial sector, particularly of banks, to international capital flows alters the transmission channels of local and international monetary shocks in SOEs. As banking industries become increasingly integrated, local banks in small open economies (hereafter "SOEs") broaden their operations in international markets, diversifying funding sources and mediating foreign financial products to domestic consumers.1) To the extent that financial intermediaries are the important bridges between monetary policy (hereafter "MP") and its macroeconomic policy targets, this changing environment in the banking industry gives rise to active debates about the consequent change of domestic MP transmission in open economies as well as their economic vulnerability to external macroeconomic and financial shocks (e.g., Bernanke, 2007; Cetorelli and Goldberg, 2012; Bruno and Shin, 2015).

The relationship between financial integration and MP transmission is not a new research topic. H owever, the relevant literature has critical limitations in explaining the consequences of financial integration for MP transmission due to the lack of consideration of the role of the banks in SOEs. Figure 1 shows that financial markets have a higher dependency on banking (Panel A) and that banks play a more vital role in mediating gl obal liquidity to the domestic sector in the financial globalization process in SOEs (Panel B) compared to a large economy, such as the U.S.2) Furthermore, the banking industry has some distinctive features that differ from direct finance markets. For instance, in most countries, financial supervisory authorities impose regulatory requirements on banks to guarantee financial stability (e.g., capital-asset ratio, macro-prudential measures). Banks also enjoy some degree of market power similar to profit

1) Bank globalization in small open economies can be referred to as (i) international banking of local banks through the international financial market and/or (ii) local banking of global banks branches through internal cross-country capital market (e.g. lending and borrowing between a head office and local branches). Throughout the paper, I refer to the former type of international banking activities as bank globalization in order to reflect the characteristics and roles of the banking sector in the process of financial integration in SOEs.

2) This paper focuses on analyzing the economies with autonomous monetary policies and flexible floating exchange rates rather than the ones dollarized. Thus, the countries illustrated in Figure 1 and analyzed in Chapter 2 are chosen because they accord with such features. 
Figure 1: Bank Credit to Private Sector and Bank External Debt A. Bank ${ }^{1}$ credit/total credit to Private Non-financial Sector ${ }^{2}$

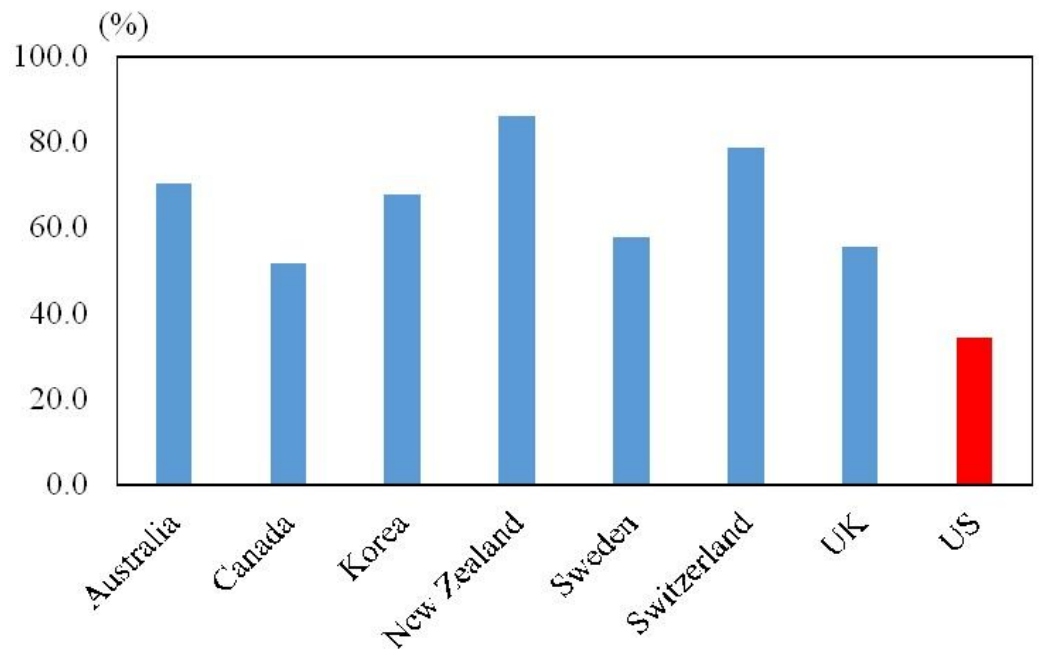

B. Bank external debt/gross external debt

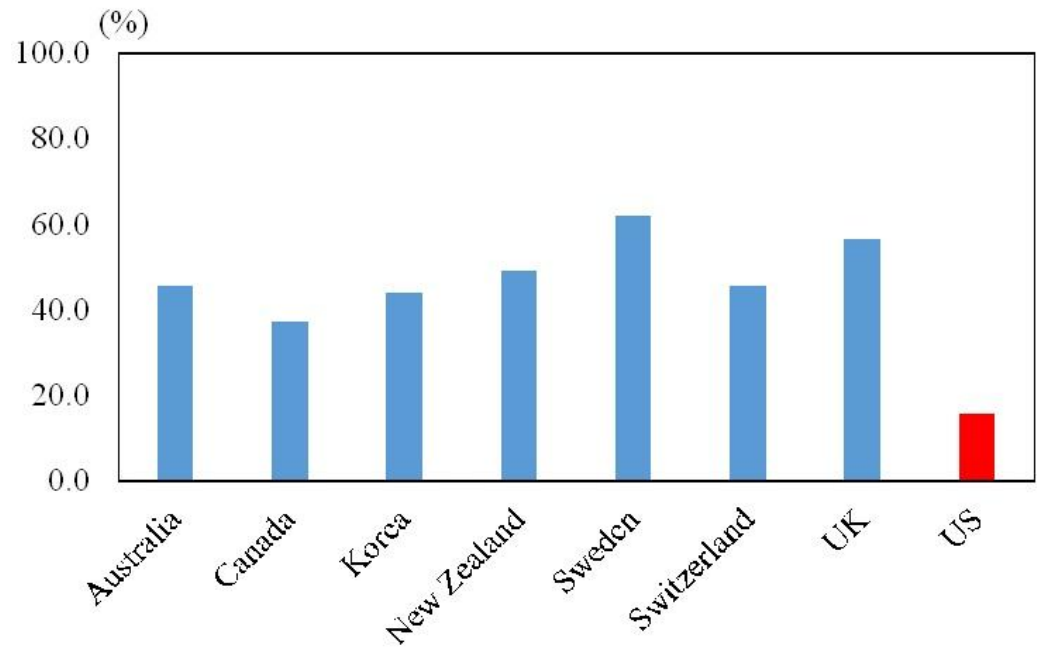

Notes: 1. Domestic depository corporations (except central banks)

2. Non-financial corporations, households, and non-profit institutions serving households

Sources: BIS, World Bank (as of the end of 2016Q3)

maximizing firms (Freixas and Rochet, 1997). However, existing studies on financial integration exclusively focus on the broad issues of capital market openness rather than on the stylized facts regarding the financial markets and 
the banking sector in SOEs.3) Therefore, the channels through which international banking affects MP transmission are still far from fully understood despite the importance of the topic in the context of the SOE's MP transmission.

To bridge the gap and examine the systemic relationship between bank globalization and MP transmission, I set up and estimate a dynamic general equilibrium model incorporating a stylized banking sector into a SOE version of Iacoviello (2005). The most notable feature of the banking sector in my model is that banks operate international banking through the international interbank market in two common forms: financing foreign operating funds and importing foreign loan contracts. Each type of international activity is closely related to banks' decisions on setting interest rates and credit supply. Thus, each activity affects the loan rate and the capital position of the local banks. I then study the effect of openness in the banking sector by comparing the results from alternative models that shut down each globalization channel sequentially.

The findings of the estimated DSGE model support Rey (2015)'s dilemma view as follows. ${ }^{4)}$ First, bank globalization attenuates local MP transmission. In case of a monetary tightening shock5), on one hand, loan rates increase less in response to a negative monetary shock compared to the responses in financial autarky (referred to as foreign interest rate channel). It is because banks set the loan rates by taking into account not only increased domestic policy rates but also unaffected international interest rates as well as appreciation of real exchange rate. A lower rise in loan rates first mitigates interest rate channel and alleviates the financial accelerator effect by not reducing the real value of borrowers' outstanding debt obligations as much. On the other hand, banks'

3) For instance, Woodford (2007) and Tille (2008) analyze the effects of financial globalization on the transmission of monetary shocks without attention to the role of financial intermediaries under the assumption of a frictionless MP transmission through domestic financial markets acting as conventional New Keynesian frameworks.

4) Rey (2015) points out that US dollar is world-wide used as a funding and investment currency and argues that this creats a global financial cycle. Thus, US financial conditions, including US MP shocks, can influence the rest of the world through global financial intermediaries and their leverage. Under the circumstances, autonomous monetary policy can be achieved only when capital flow is controlled and the exchange rate is freely floating, unlike the traditional view of Mundellian trilemma.

5) Note that a monetary easing shock has symmetric effects on the model economy. 
international operation deters themselves from reducing their issuance of loans after a monetary contraction, thereby attenuating the transmission of MP shock (foreign liquidity channel). In financial autarky, the decline of deposits following policy rate rises pressures banks to reduce their supplies on bank loans to meet the capital-asset ratio. This reduction leads to a decline in household and firm activities. H owever, the availability of foreign liquidity due to a globalized banking can buffer the shrinkage of bank assets to some extent against negative policy effects.

Second, bank globalization induces bank rates to respond more strongly to foreign MP shocks. In the alternative model without international banking, foreign monetary shocks affect domestic retail loan rates only indirectly through the adjustment of the local policy rate according to a no-arbitrage condition in the foreign exchange market or exchange rate pass-through. H owever, if banks can import foreign loan accounts and thus set loan rates taking into account the domestic policy rate, international interbank rates and real exchange rate, a new channel is opened, in addition to the aforementioned indirect channels, through which foreign monetary surprise can directly influence local loan rates. This new channel is empirically supported by recent findings in Passari and Rey (2015), showing that mortgage spread in SOEs responds positively to U.S monetary shocks with the same degree of magnitude as the domestic U.S mortgage spread.

This paper contributes to the literature in the following ways. First, to the best of my knowledge, this paper is the first to demonstrate a direct link between bank globalization and MP transmission under the general equilibrium framework enriched with a stylized banking sector. In addition to international banking activities, the model adopts regulatory interventions when obtaining bank liabilities and market power in the banking sector. Over the last decade, a growing number of studies have investigated the role of these features in the banking sector in MP transmission.6) Scholars researching the role of the

6) A burgeoning literature sheds light on the conditions from the supply side (i.e. financial intermediaries) of credit markets (Van den Heuvel 2008, Gerali et al. 2010). These studies demonstrate the channels in which typical MP transmission can be distorted by credit frictions embedded in the process of financial intermediaries money mediation, such as the regulatory capital-to-asset ratio (bank capital channel) and/or the degree of banking market competition (bank attenuator channel). 
banking sector in open capital markets are increasingly investigating the role of financial integration in cross-border propagation of liquidity shock.7) H owever, relatively less studies have paid attention to how bank globalization alters the channels of MP transmission under the structures, particularly in the theoretical literature. Most closely related to my study are the studies of Cetorelli and Goldberg (2012) and Goldberg (2013), who empirically demonstrate that global banks isolate themselves from the impact of monetary surprises through their abilities to raise funds abroad as well as influence MP autonomy heterogeneously, depending on the frictions in the international capital market and the stickiness of claims. Although successful in providing some empirical evidence of the relationship between bank globalization and MP transmission, these researchers do not explain why such a link is formulated and how it affects other sectors, in part because of their partial equilibrium approaches. Conversely, this paper investigates the overall change in the supply side of the credit market to uncover the role of bank globalization in MP transmission in a general equilibrium framework.

Second, this paper provides an analysis by subdividing and quantitatively assessing the effects of international banking on MP transmission. The link between bank globalization and MP transmission is ambiguous a priori in the sense that bank globalization involves an adjustment of banks' overall conditions for money mediation. For instance, in the open banking market, banks do not necessarily rely on the domestic credit in their operation. This may change their strategies on interest rate setting and capital position. Two common forms of international banking operation, loan contract import and foreign liquidity borrowing, allow us to understand the detailed effects of banking sector openness.8) By determining the effect of each form, this study shows how bank globalization affects MP transmission and which channel is dominant. Each form directly affects loan rates and banks' capital position. By contrast, existing studies

7) See recent work on the international transmission of crises by Schnabl 2012, Kalemli-Ozcan, Papaioannou and Perri 2013, Devereux and Yu 2014, Kang and Dao 2012 and others.

8) Rosenberg and Tirpak (2008) point out the main drivers of banks' foreign currency borrowing: the demand for foreign currency payments in international trade, the domestic capital shortage caused by credit expansion, and interest rate differentials between local and foreign currency. 
that incorporate a banking sector into the model usually consider only one side, thereby providing a limited perspective for understanding the overall features of change caused by bank globalization (e.g., credit amount: Kollmann, 2013; Kang and Dao, 2012; interest rate: Brzoza-Brzezina and Makarski, 2011).

The rest of this paper is organized as follows. Section 2 presents empirical evidence on bank globalization using a VAR model. Section 3 describes the baseline SOE DSGE model. Section 4 discusses the calibration/estimation procedure. Section 5 provides an overview of the transmission mechanism of MP shocks through the banking sector and the results of domestic and international monetary contraction. Section 6 concludes the paper.

\section{Vector Autoregressive (VAR) Analysis}

Before describing the theoretical channels of interaction between international banking and MP transmission, this section first documents the key relationship in data, specifically between monetary shocks and bank lending rates, by giving an overview of VAR evidence. The VAR model is composed of the U.S. federal funds rate, logs of seasonally adjusted industrial production, logs of domestic consumer price indexes, domestic policy rates, short-term (3-month) interest rates, bank lending rates, and logs of nominal exchange rates. The three focal countries the U.K., Korea, and Canada are representative SOEs that depend heavily on world economies, approximated here by the U.S., from both macroeconomic and financial market aspects. To identify a stable MP regime, the following quarterly data are used for each country: Canada (1996Q 1 2013Q4), Korea (1999Q1 2013Q4), New Zealand (1992Q1 2013Q4), Switzerland (1992Q 1 2013Q4) and the U.K. (1997Q1 2013Q4). The lag order is determined by two quarters for all focal countries according to various information criteria. These SOEs are more largely dependent upon the banking sector in intermediating credit domestically and internationally than the U.S., as depicted in Figure 1. Furthermore, these countries have adopted inflation targeting regimes and adjusted short-term interest rates as MP operating 
instruments. For comparative purpose, I also estimate a similar model with U.S. data as a benchmark. Four external variables - a crisis dummy, the international commodity price index, the dollar index, and VIX index - are added to insulate exogenous components that may affect endogenous variables in the VAR system contemporaneously (e.g., Kim, 2001; Bjørnland, 2009).

I use a standard Cholesky decomposition to identify VAR (ordered listed as above).9) For convenience of comparison, I graph all of the impulse responses of the interest rates to one percentage point of domestic MP shock in each panel in Figure 2. The shaded area plotted in the graph is the $90 \%$ bootstrap probability band of loan rate response. Overall, the scales of the effect are shown to be smaller in bank loan rates (red line) than those in policy rates (black line) and short-term rates (blue line) at the time of a contractionary MP shock in SOEs except Canada. Notably, this feature is distinct from the responses in the U.S. (Panel A) where loan rates react similarly to the movement of the federal fund rate. The fact that the bank rates react less to policy shock could be because the banking sector in focal countries has some degree of market power (Gerali et al., 2010; $\mathrm{Ha}$ and So, 2013). However, as we shall see in Section 5, the attenuation of MP transmission in banking could also appear due to the bank's international activity.

Figure 3 plots the impulse responses of the domestic policy rate (black line) and loan rates (red line) to one percentage point of foreign (U.S.) MP shock. Many open economy studies typically assume that foreign monetary shocks transmit internationally through the adjustment of short-term rates in a SOE according to interest rate parity (Obstfeld and Rogoff, 1995; Kim, 2001). Considering the international transmission channel as well as the frictions in the banking sector found above, the response of loan rates to foreign monetary shock is predicted to be less than that of the home policy rate (foreign MP shock $\rightarrow$ SOE policy rate $\rightarrow$ (frictions) $\rightarrow$ SOE loan rates). However, the result

9) I test the robustness of the identifying short-run restriction by specifying an alternative ordering of variables, specifically the SOE's interest rates, to consider the simultaneity issues raised among financial variables (Gertler and Karadi 2015, Bjørnland 2009). The results stay robust to these variations. 
Figure 2: Impulse Responses of Interest Rates to Domestic MP Shock (1\%p)

A. U.S.

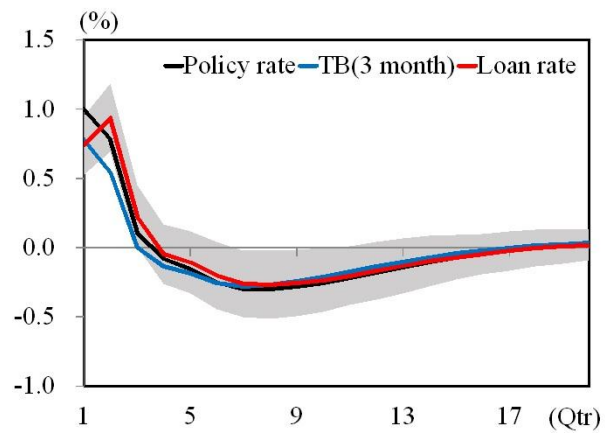

C. Canada

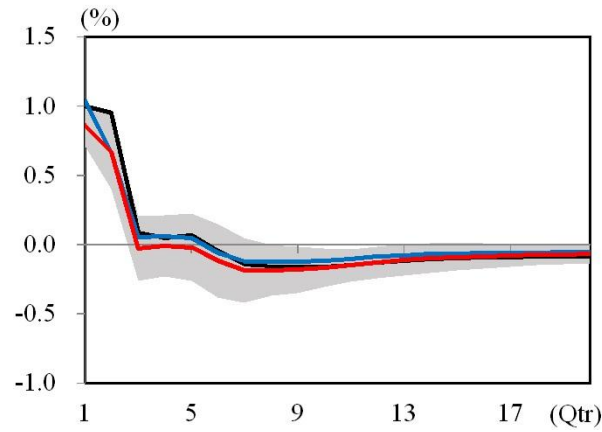

E. New Zealand

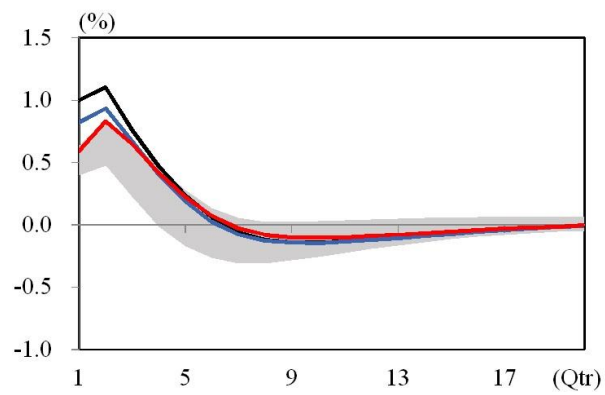

B. U.K.

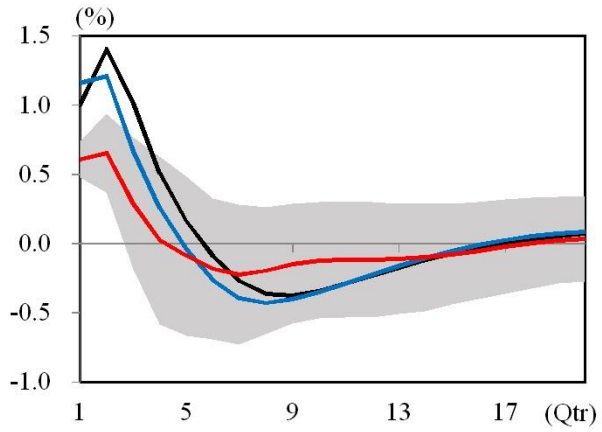

D. Korea

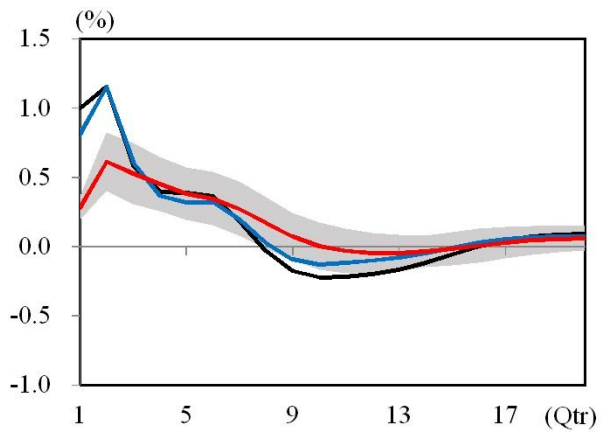

F. Switzerland

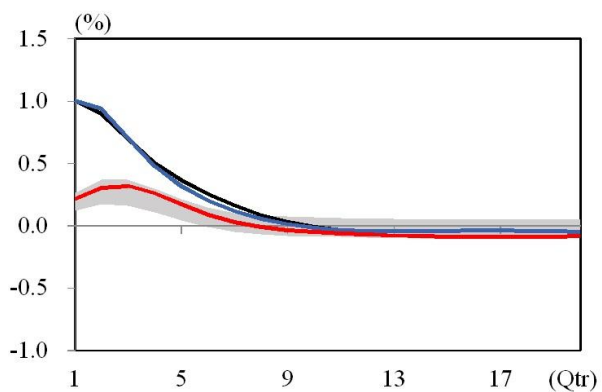

Notes: Shaded area is $90 \%$ bootstrap interval (based on 5,000 draws) of domestic loan rate response. 
Figure 3: Impulse Responses of Interest Rates to Foreign MP Shock (1\%p)
A. U.K.
B. Canada
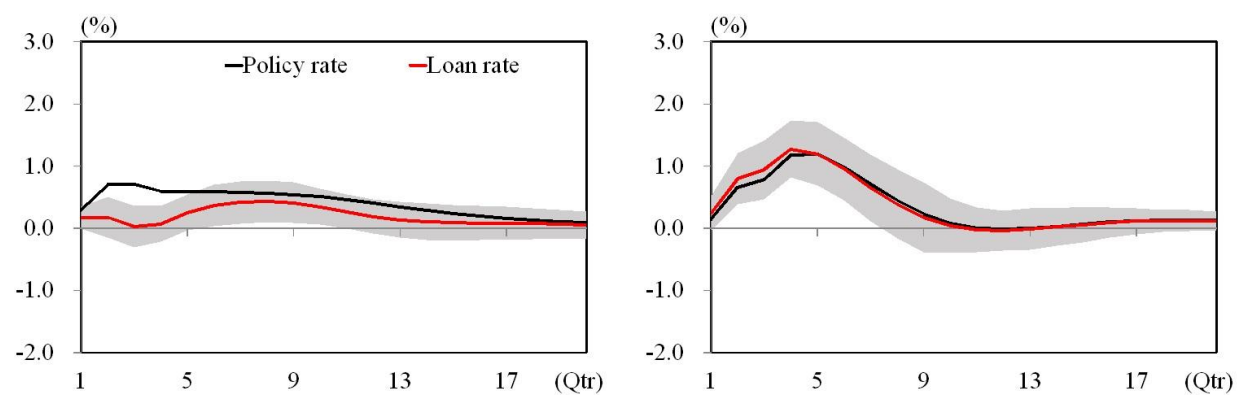

C. Korea

D. New Zealand
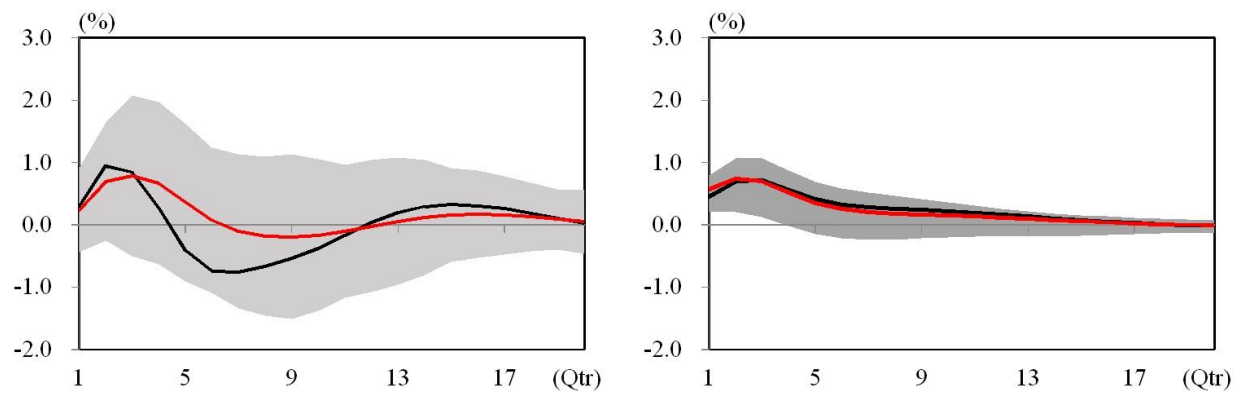

E. Switzerland

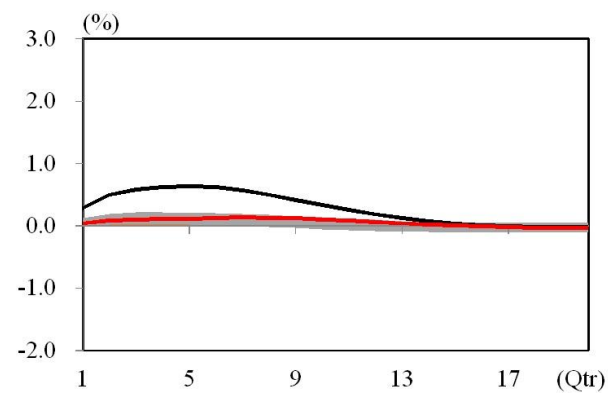

Notes: Shaded area is $90 \%$ bootstrap interval (based on 5,000 draws) of domestic loan rate response. 
of VAR seems to be inconsistent with the prediction of this framework. Loan rates in SOEs respond to foreign MP shock as much as policy rates except the Switzerland where its response is significantly lower than the policy rate. This result may indicate the presence of additional channels of international monetary transmission to local loan rates (foreign MP shock $\rightarrow$ SOE loan rates) besides indirect transmission through the SOE policy rate. A theoretical model will be described in next section.

\section{Model}

The world economy is composed of a continuum of SOEs that are represented by the unit interval. Each SOE is populated by patient households, impatient households, entrepreneurs, and banks, with each group having a unit mass. Households consume, work, accumulate housing stock, and make one-period deposits (patient households) or take out one-period loans (impatient households).10) Entrepreneurs produce homogenous intermediate goods using capital, real estate, and labor supplied by households. Furthermore, entrepreneurs can also borrow from banks to finance capital purchases. In between the households and the entrepreneurs, banks intermediate funds by supplying financial assets while enjoying some degree of monopoly power. They give out collateralized loans to both impatient households and entrepreneurs, and obtain funding via deposits and foreign liquidity borrowing.

Three types of frictions coexist and interact in the financial sector. First, when having a bank loan, borrowers face a collateral constraint which is tied to the present value of their housing stock. Second, banks face credit constraints in how much they can raise from home depositors and foreign economies. Third, due to a bank's market power, bank rates on loans and deposits are set differently from the domestic interbank rate.

10) I consider heterogeneity in households to apply financial frictions to both firms and households (e.g. Iacoviello, 2005; Gerali et al., 2010). Under the assumption of different agents' discount factors, this set-up allows positive flows of fund among agents (patient households $\rightarrow$ banks $\rightarrow$ impatient households and entrepreneurs). 
Figure 4: Model Structure

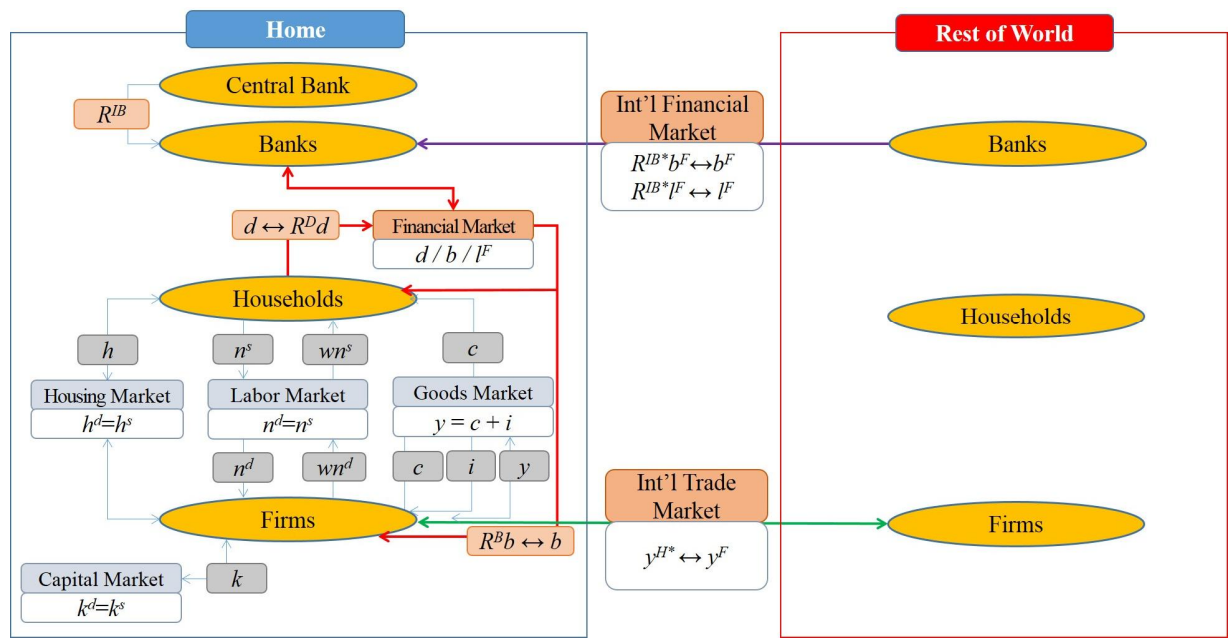

\section{Patient Households}

A continuum of patient households consume composite good $c_{P, t}$ and housing $h_{P, t}$, deposit $d_{t}$, and supply labor $n_{P, t}$. The expected utility of a representative patient household is given as

$$
\mathrm{E}_{0} \sum_{t=0}^{\infty} \beta_{P}^{t}\left[\ln c_{P, t}+j_{t} \ln h_{P, t}-\left(n_{P, t}\right)^{\eta} / \eta\right]
$$

where $E_{0}$ is a conditional expectation at $t=0, \beta_{P}$ is the utility discount factor and $\eta$ is the elasticity of marginal utility of labor. $j_{t}$ is a random variable which reffects the change in housing preference. It follows an $A R(1)$ process with i.i.d. normal innovations such as Eq (2).

$$
\ln j_{t}=\left(1-\theta_{j}\right) \ln j+\theta_{j} \ln j_{t-1}+\varepsilon_{j, t}, \varepsilon_{j, t} \sim N\left(0, \sigma_{j}^{2}\right)
$$

The patient households use labor income $w_{P, t} n_{P, t}$ and dividend income $\Pi_{P, t}^{E}$ and $\Pi_{P, t}^{B}$ generated from owning firms and banks, respectively, as well as its 
real principal and interest income from deposits $\left.R_{d, t-1} d_{t-1} / \pi_{t} 11\right)$ to finance their consumption, housing and deposits. The patient household's budget constraint (in real terms) is

$$
c_{P, t}+q_{t} h_{P, t}+d_{t} \leq w_{P, t} n_{P, t}+q_{t} h_{P, t-1}+\frac{R_{d, t-1}}{\pi_{t}} d_{t-1}+\Pi_{P, t}^{E}+\Pi_{P, t}^{B}
$$

where $q_{t}$ and $\pi_{t}$ denote, respectively, the price of housing and the inflation rate. Solving this problem yields first-order conditions for the consumption Euler equation, housing demand and labor supply:

$$
\begin{gathered}
\frac{1}{c_{P, t}}=\mathrm{E}_{t}\left[\frac{\beta_{P}}{c_{P, t+1}} \frac{R_{d, t}}{\pi_{t+1}}\right] \\
\frac{q_{t}}{c_{P, t}}=\frac{j_{t}}{h_{P, t}}+\mathrm{E}_{t}\left[\beta_{P} \frac{q_{t+1}}{c_{P, t+1}}\right] \\
w_{P, t}=\left(n_{P, t}\right)^{\eta-1} c_{P, t}
\end{gathered}
$$

Notice that the consumers' consumption aggregate is determined as a constant elasticity of substitution (CES) index composed of both home $c_{t}^{H}$ and import goods $c_{t}^{F}$ :

$$
c_{t}=\left[a^{\frac{1}{\omega}}\left(c_{t}^{H}\right)^{\frac{\omega-1}{\omega}}+(1-a)^{\frac{1}{\omega}}\left(c_{t}^{F}\right)^{\frac{\omega-1}{\omega}}\right]^{\frac{\omega}{\omega-1}}
$$

where $a$ and $w>0$ are the home bias parameter and intra-temporal elasticity of substitution(EOS) between home and import consumption goods, respectively. Composites for domestic and foreign goods are defined as $c_{t}^{H}=\left[\int_{0}^{1} c_{t}^{H}(z)^{\frac{\varepsilon^{H}-1}{\varepsilon^{H}}} d z\right]^{\frac{\varepsilon^{H}}{\varepsilon^{H}-1}}$ and $c_{t}^{F}=\left[\int_{0}^{1}\left(c_{t}^{F}(z)\right)^{\frac{\varepsilon^{F}-1}{\varepsilon^{F}}} d z\right]^{\frac{\varepsilon^{F}}{\varepsilon^{F}-1}}$, and $\varepsilon^{H}$

11) Similar to Iacoviello (2005), I assume that deposit and loan contracts are set in nominal terms. Here, $R_{d, t}$ is a gross return and $\pi_{t}$ is the price change between $t-1$ and $t\left(=P_{t} / P_{t-1}\right)$. 
and $\varepsilon^{F}>1$ are the EOSs across goods.12) Given the CES aggregator, the demand for domestic goods and the demand for imports are represented as follows.

$$
c_{t}^{H}=a\left(\frac{P_{t}^{H}}{P_{t}}\right)^{-\omega} c_{t} \quad \text { and } \quad c_{t}^{F}=(1-a)\left(\frac{P_{t}^{F}}{P_{t}}\right)^{-\omega} c_{t}
$$

where the corresponding price index is

$$
P_{t}=\left[a\left(P_{t}^{H}\right)^{1-\omega}+(1-a)\left(P_{t}^{F}\right)^{1-\omega}\right]^{\frac{1}{1-\omega}}
$$

\section{Impatient Households}

Similar to patient households, impatient households consume goods $c_{I, t}$ and housing $h_{I, t}$ and supply labor $n_{I, t}$. The impatient households maximize the following expected lifetime utility:

$$
\mathrm{E}_{0} \sum_{t=0}^{\infty} \beta_{I}^{t}\left[\ln c_{I, t}+j_{t} \ln h_{I, t}-\left(n_{I, t}\right)^{\eta} / \eta\right]
$$

However, they use labor income and new loans $b_{I, t}$ to finance consumption, housing and the reimbursement of loans borrowed in the previous period $R_{b I, t-1} b_{I, t-1} / \pi_{t}$. In addition, they can borrow only up to a certain portion $\left(m_{I}\right)$ of the expected real value of their housing stock. The budget constraint and the borrowing constraint are

$$
\begin{gathered}
c_{I, t}+q_{t} h_{I, t}+\frac{R_{b I, t-1}}{\pi_{t}} b_{I, t-1} \leq w_{I, t} n_{I, t}+q_{t} h_{I, t-1}+b_{I, t} \\
R_{b I, t} b_{I, t} \leq m_{I} \mathrm{E}_{t}\left[q_{t+1} h_{I, t} \pi_{t+1}\right]
\end{gathered}
$$

12) For simplicity, the model does not distinguish between EOS between individual goods and EOS between home and import goods (Obstfeld and Rogoff, 1995). 
where $m_{I}$ is household's loan-to-value (LTV) ratio. The first-order conditions of impatient households are consumption, housing choice and labor supply.

$$
\begin{gathered}
\frac{1}{c_{I, t}}=\mathrm{E}_{t}\left[\frac{\beta_{I}}{c_{I, t+1}} \frac{R_{b I, t}}{\pi_{t+1}}\right]+\lambda_{I, t}^{\prime} R_{b I, t} \\
\frac{q_{t}}{c_{I, t}}=\frac{j_{t}}{h_{I, t}}+\mathrm{E}_{t}\left[\beta_{I} \frac{q_{t+1}}{c_{I, t+1}}+\lambda_{I, t}^{\prime} m_{I} q_{t+1} \pi_{t+1}\right] \\
\frac{w_{I, t}}{c_{I, t}}=\left(n_{I, t}\right)^{\eta-1}
\end{gathered}
$$

where $\lambda_{I, t}^{\prime}$ is the Lagrangian multiplier of borrowing constraint.

\section{Entrepreneurs}

Entrepreneurs care only about their consumption $c_{E, t}$, and they maximize the following expected utility.

$$
\mathrm{E}_{0} \sum_{t=0}^{\infty} \beta_{E}^{t} \ln c_{E, t}
$$

Entrepreneurs produce homogeneous intermediate goods $y_{W, t}$ with labor hired from households, capital $k_{t}$ accumulated through investment, and real estate $h_{E, t}$ by using a Cobb-Douglas type technology as shown in Eq (15). $A_{t}$ is total factor productivity, which follows an exogenous $A R(1)$ process.13)

$$
y_{W, t}=A_{t}\left(k_{t-1}\right)^{\mu}\left(h_{E, t-1}\right)^{v}\left[\left(n_{P, t}\right)^{\alpha}\left(n_{I, t}\right)^{1-\alpha}\right]^{1-\mu-v}
$$

Entrepreneurs finance their consumption, real estate, labor services, capital accumulation and reimbursement of loans by obtaining the revenue from their intermediate goods sales and taking out new loans $b_{E, t}$.

13) The $\operatorname{AR}(1)$ coefficient is $\theta_{A}$, and the standard deviation is $\sigma_{A}$. 


$$
c_{E, t}+i_{t}+w_{P, t} n_{P, t}+w_{I, t} n_{I, t}+q_{t} h_{E, t}+\frac{R_{b E, t-1}}{\pi_{t}} b_{E, t-1}+\xi_{K, t} \leq \frac{y_{W, t}}{x_{t}}+q_{t} h_{E, t-1}+b_{E, t}
$$

where it $i_{t}\left(=k_{t}-(1-\delta) k_{t-1}\right)$ is investment, $x_{t}\left(=P_{t} / P_{W, t}\right)$ is the mark-up of final over wholesale goods, and $\xi_{K, t}=\frac{\kappa_{i}}{2 \delta}\left(\frac{i_{t}}{k_{t-1}}-\delta\right)^{2} k_{t-1}$ is the convex capital stock adjustment cost. Additionally, the amount of loans that entrepreneurs can borrow from banks must be less than a certain portion $\left(m_{E}\right)$ of the expected value of their real estate. ${ }^{14)}$

$$
R_{b E, t} b_{E, t} \leq m_{E} E_{t}\left[q_{t+1} h_{E, t} \pi_{t+1}\right]
$$

Entrepreneurs' first-order conditions are the consumption Euler equation, capital demand, real estate demand and labor demands.

$$
\begin{gathered}
\frac{1}{c_{E, t}}=\mathrm{E}_{t}\left[\frac{\beta_{E}}{c_{E, t+1}} \frac{R_{b E, t}}{\pi_{t+1}}\right]+\lambda_{E, t}^{\prime} R_{b E, t} \\
\frac{1}{c_{E, t}}\left(1+\frac{\kappa_{i}}{\delta}\left(\frac{i_{t}}{k_{t-1}}-\delta\right)\right) \\
\left.=\mathrm{E}_{t}\left[\frac{\beta_{E}}{c_{E, t+1}}\left(1-\delta+\mu \frac{y_{W, t+1}}{x_{t+1}} \frac{1}{k_{t}}+\frac{\kappa_{i}}{\delta}\left(\frac{i_{t+1}}{k_{t}}-\delta\right)\left(\frac{1}{2}\left(\frac{i_{t+1}}{k_{t}}+\delta\right)+1-\delta\right)\right]\right)\right] \\
\frac{q_{t}}{c_{E, t}}=\mathrm{E}_{t}\left[\frac{\beta_{E}}{c_{E, t+1}}\left(q_{t+1}+\frac{y_{W, t+1}}{x_{t+1}} v \frac{1}{h_{E, t}}\right)\right]+\lambda_{E, t}^{\prime} m_{E} \mathrm{E}_{t}\left[q_{t+1} \pi_{t+1}\right] \\
w_{P, t}=\alpha(1-\mu) \frac{y_{W, t}}{x_{t}} \frac{1}{n_{P, t}} \\
w_{I, t}=(1-\alpha)(1-\mu) \frac{y_{W, t}}{x_{t}} \frac{1}{n_{I, t}}
\end{gathered}
$$

14) I assume that firms use real estate as collateral as in Iacoviello (2005), noting that firms in SOEs are usually requested to provide real estate, including housing and land, to banks as collateral rather than capital. For example, as of late 2008 in Korea, real estate comprised $88 \%$ of the total collateral value pledged by firms and $94 \%$ of that pledged by households (Ha and So 2013). 


\section{Firms}

There are two sets of firms. Firms in the import goods sector purchase foreign intermediate goods at given world prices $P_{t}^{*}$ and transform them into differentiated import goods $y_{t}^{F}$, whereas firms in the home goods sector produce differentiated goods $y_{t}^{H}$ using domestic intermediate goods purchased at the wholesale price $P_{W, t}$ from entrepreneurs at no cost. Each firm $z$ then sells their unique variety at a mark-up over world price or wholesale price. Both face a quadratic price adjustment cost, as in Rotemberg (1982).15)

The domestic firm $z$ would set price $P_{t}^{H}(z)$ for the domestic goods to maximize the net present value of future profits

$$
E_{0} \sum_{t=0}^{\infty} \Lambda_{0, t}^{E}\left[P_{t}^{H}(z) y_{t}^{H}(z)-P_{W, t} y_{t}^{H}(z)-\frac{\kappa_{p}^{H}}{2}\left(\pi_{t}^{H}(z)-\left(\pi_{t-1}^{H}\right)^{\zeta}\left(\pi^{H}\right)^{1-\zeta}\right)^{2} p_{t}^{H} y_{t}^{H}\right]
$$

subject to the demand function, $\left.y_{t}^{H}(z)=\left(\frac{P_{t}^{H}(z)}{P_{t}^{H}}\right)^{-w} y_{t}^{H} \cdot 16\right) \quad \Lambda_{0, t}^{E}$ is an inter-temporal discount rate between time 0 and $t$. Note that the firm is owned by patient households so that inter-temporal discount rate is taken from the problems of patient households. I assume that the price of home goods is indexed to past and steady-state inflation, with relative weights parameterized by $\zeta$ and $1-\zeta$, respectively. Firms in the domestic sector must pay a quadratic cost of price adjustment when they change their prices beyond indexation. $\kappa_{p}^{H}$ is an adjustment cost parameter. After imposing symmetry, the first-order condition yields the following hybrid Phillips curve in the home goods market.

15) Calvo-pricing and Rotemberg-pricing are two widely used assumptions in the New-Keynesian literature for price stickiness. To a first order of approximation, both pricing assumptions yield similar dynamics of the economy. However, it is well known that, at a higher order of approximation, these assumptions entail different welfare costs. See Blanchard and Fischer (1989 Ch. 8.2), and Lombardo and Vestin(2008) for further details.

16) An index for the aggregate output for each country is assumed to be analogous to the one introduced for consumption. 


$$
\begin{aligned}
1-\omega+\frac{\omega}{x_{t}}- & \kappa_{p}^{H}\left(\pi_{t}^{H}-\left(\pi_{t-1}^{H}\right)^{\zeta}\left(\pi^{H}\right)^{1-\zeta}\right) \pi_{t}^{H} \\
& +\beta_{P} \frac{c_{P, t}}{c_{P, t+1}} \kappa_{p}^{H} \mathrm{E}_{t}\left[\left(\pi_{t+1}^{H}-\left(\pi_{t}^{H}\right)^{\zeta}\left(\pi^{H}\right)^{1-\zeta}\right)\left(\pi_{t+1}^{H}\right)^{2} \frac{y_{t+1}^{H}}{y_{t}^{H}}\right]=0
\end{aligned}
$$

As shown in Eq (25), log-linearizing Eq (24) (with hat representing the log deviation from the steady state) indicates that domestic inflation is driven by past and future inflation, and mark-up rate.

$$
\widehat{\pi_{t}^{H}}=-\frac{\omega-1}{\kappa_{p}^{H}\left(1+\beta_{P} \zeta\right)} \widehat{x_{t}}+\frac{\beta_{P}}{1+\beta_{P} \zeta} \mathrm{E}_{t} \widehat{\pi_{t+1}^{H}}+\frac{\zeta}{1+\beta_{P} \zeta} \widehat{\pi_{t-1}^{H}}
$$

where $\widehat{\pi_{t}^{H}}$ is the inflation of home goods defined as the price change of domestic goods between $t$ and $t-1$, i.e. $\widehat{\pi_{t}^{H}} \equiv \widehat{P_{t}^{H}}-\widehat{P_{t-1}^{H}}$.

As with the price of home goods, the price of imported goods is sticky. Importing firms face a quadratic adjustment cost when they determine the prices for import $P_{t}^{F}(z)$ to maximize the profit

$$
\mathrm{E}_{0} \sum_{t=0}^{\infty} \Lambda_{0, t}^{E}\left[P_{t}^{F}(z) y_{t}^{F}(z)-e_{t} P_{t}^{*}(z) y_{t}^{F}(z)-\frac{\kappa_{p}^{F}}{2}\left(\pi_{t}^{F}(z)-\left(\pi_{t-1}^{F}\right)^{\zeta}\left(\pi^{F}\right)^{1-\zeta}\right)^{2} p_{t}^{F} y_{t}^{F}\right]
$$

subject to $y_{t}^{F}(z)=\left(\frac{P_{t}^{F}(z)}{P_{t}}\right)^{-w} y_{t}^{F} \cdot \kappa_{p}^{F}$ is the adjustment cost parameter measuring the degree of price rigidity for imported good. The first-order condition for the import goods market is obtained as Eq (27), or log-linearized expression (28).

$$
\begin{aligned}
1-\omega+\omega \psi_{t}-\kappa_{p}^{F}\left(\pi_{t}^{F}-\left(\pi_{t-1}^{F}\right)^{\zeta}\left(\pi^{F}\right)^{1-\zeta}\right) \pi_{t}^{F} \\
+\beta_{P} \frac{c_{P, t}}{c_{P, t+1}} \kappa_{p}^{F} \mathrm{E}_{t}\left[\left(\pi_{t+1}^{F}-\left(\pi_{t}^{F}\right)^{\zeta}\left(\pi^{F}\right)^{1-\zeta}\right)\left(\pi_{t+1}^{F}\right)^{2} \frac{y_{t+1}^{F}}{y_{t}^{F}}\right]=0
\end{aligned}
$$




$$
\widehat{\pi_{t}^{F}}=\frac{\omega-1}{\kappa_{P}^{F}\left(1+\beta_{P} \zeta\right)} \widehat{\psi_{t}}+\frac{\beta_{P}}{1+\beta_{P} \zeta} \mathrm{E}_{t} \widehat{\pi_{t+1}^{F}}+\frac{\zeta}{1+\beta_{P} \zeta} \widehat{\pi_{t-1}^{F}}
$$

where $\psi_{t}=e_{t} P_{t}^{*} / P_{F, t}$ denotes the law of one price (LOP) gap defined as the difference between the world price and domestic price of imports, and $\pi_{t}^{F}$ is the inflation of imported goods denominated in home currency. Price change of imported goods is thus determined by past and future inflation, and deviations from LOP.

\section{Inflation, Real Exchange Rate and Terms of Trade}

In an open economy, CPI inflation $\pi_{t}$ is distinct from home goods inflation $\pi_{t}^{H}$ because the price of imported goods influences the domestic economy. From the definition of CPI, the log-linearized expression of $\pi_{t}$ can be expressed as

$$
\widehat{\pi_{t}}=a \widehat{\pi_{t}^{H}}+(1-a) \widehat{\pi_{t}^{F}}
$$

The terms of trade, which are defined as the relative prices of home goods to imported goods, i.e., $S \equiv P_{t}^{H} / P_{t}^{F}$, are linked to home goods inflation and CPI inflation according to

$$
\widehat{\pi_{t}}=\widehat{\pi_{t}^{H}}-(1-a) \Delta \widehat{S_{t}}
$$

I assume that LOP does not hold. Deviations from purchasing power parity (PPP) in this model arises from deviation from LOP. The real exchange rate $Q_{t}\left(\equiv e_{t} P_{t}^{*} / P_{t}\right)$ can be expressed as

$$
\widehat{Q_{t}}=a \widehat{S_{t}}+\widehat{\psi_{t}}
$$




\section{Banks}

Banks, as an intermediary, are in charge of all financial transactions among households and entrepreneurs in the model economy. To capture the market power in the banking sector, banks are assumed to be monopolistically competitive. Each bank $j$ is composed of a retail and a wholesale unit, and each unit can access domestic and international interbank markets. The retail branch obtains funding by purchasing differentiated deposits from patient households and provides differentiated loans made from credits taken in the domestic and international interbank markets to impatient households and entrepreneurs. The wholesale branch manages the capital position of the bank using the asset and liability raised in the domestic and international interbank markets while providing financial instruments to its retail unit. They also face regulatory intervention in their operations, such as capital adequacy constraints and foreign debt requirements.

\subsection{Loan and Deposit Demand}

I model monopoly power in the banking industry with a Dixit-Stiglitz framework after Gerali et al (2010). First, I assume that a unit of deposit contracts purchased by patient households is a composite constant elasticity of substitution (CES) basket of differentiated deposits supplied by a bank $j .17$ )

$$
d_{t}=\left[\int_{0}^{1} d_{t}(j)^{\frac{\varepsilon_{d}-1}{\varepsilon_{d}}} d j\right]^{\frac{\varepsilon_{d}}{\varepsilon_{d}-1}}
$$

where $\varepsilon_{d}$ is an elasticity of substitution of deposits. The demand for deposit as the outcome of the banks' deposit-taking operation can be derived by solving the cost minimization problem. Banks sell deposit contracts at the price $1 / R_{d}$. Thus,

17) For simplicity, I treat the EOSs between deposits and between loans as exogenously determined. 
minimizing over $d_{t}(j)$ the gross interest payment given by the formula (33) subject to (32) yields the demand for deposits of patient households. ${ }^{18)}$

$$
\int_{0}^{1} \frac{1}{R_{d, t}(j)} d_{t}(j) d j
$$

Similarly to deposits, I assume that loan contracts purchased by impatient households and entrepreneurs are a composite CES basket of differentiated loans intermediated by a bank $j$.

$$
b_{s, t}=\left[\int_{0}^{1} b_{s, t}(j)^{\frac{\varepsilon_{b s}-1}{\varepsilon_{b s}}} d j\right] \frac{\frac{\varepsilon_{b s}}{\varepsilon_{b s}-1}}{}
$$

for $s=I, E . \varepsilon_{b s}$ denotes an elasticity of substitution of loans. Demand for loans to impatient households and firms can be obtained from maximizing over $b_{s, t}(j)$ the gross loan revenue given by

$$
\int_{0}^{1} R_{b s, t}(j) b_{s, t}(j) d j
$$

subject to (34).

The demand for deposits and the demand for loans are

$$
\begin{aligned}
d_{t}(j) & =\left(\frac{R_{d, t}(j)}{R_{d, t}}\right)^{\varepsilon_{d}} d_{t} \\
b_{s, t}(j) & =\left(\frac{R_{b s, t}(j)}{R_{b s, t}}\right)^{-\varepsilon_{b s}} b_{s, t}
\end{aligned}
$$

\subsection{Wholesale Branch}

The perfectly competitive wholesale branch controls the balance sheet position of the bank. On the liability side, the wholesale branch takes wholesale deposits

18) Note that this formulation is equivalent to a formulation where banks maximize profit from taking deposits defined as $\frac{1}{R_{d, t}} d_{t}-\int_{0}^{1} \frac{1}{R_{d, t}(j)} d_{t}(j) d j$ 
$d_{t}$ through retail units and raises foreign funds $l_{t}^{F}$ on the international interbank market. On the asset side, the branch gives out wholesale loans $b_{I, t}^{H}$ and $b_{E, t}^{H}$ to retail branch.

A wholesale unit maximizes the expected utility (38) over $c_{b, t}, d_{t}, b_{I, t}, b_{E, t^{\prime}}$ and $l_{t}^{F}$

$$
\mathrm{E}_{0} \sum_{t=0}^{\infty} \beta_{B}^{t} \ln c_{B, t}
$$

subject to budget constraint:

$$
\begin{aligned}
c_{B, t}+ & \frac{R_{t-1}^{I B}}{\pi_{t}} d_{t-1}+b_{I, t}^{H}+b_{E, t}^{H}+Q_{t} \frac{R_{t-1}^{I B^{*}}}{\pi_{t}} l_{t-1}^{F} \\
& \leq d_{t}+\frac{R_{t-1}^{I B}}{\pi_{t}}\left(b_{I, t-1}^{H}+b_{E, t-1}^{H}\right)+Q_{t} l_{t}^{F}-\xi_{d, t}-\xi_{b I, t}-\xi_{b E, t}-\xi_{l, t}
\end{aligned}
$$

where $c_{B, t}$ is the wholesale unit's consumption, $R_{t}^{I B}$ and $R_{t}^{I B^{*}}$ are domestic and international interbank rates, 19$) \quad$ and $\quad \xi_{d, t} \equiv \frac{\phi_{d}}{2}\left(\Delta d_{t}\right)^{2}, \quad \xi_{b I, t} \equiv \frac{\phi_{b I}}{2}\left(\Delta b_{I, t}^{H}\right)^{2}$, $\xi_{b E, t} \equiv \frac{\phi_{b E}}{2}\left(\Delta b_{E, t}^{H}\right)^{2}$, and $\xi_{l, t} \equiv \frac{\phi_{l}}{2}\left(\Delta l_{t}^{F}\right)^{2}$ are quadratic portfolio adjustment costs.20) To reffect the standard capital requirements that are imposed on banks, I assume that the amount of capital (total asset $b_{I, t}+b_{E, t}$ minus liabilities $\left.d_{t}+Q_{t} l_{t}^{F}\right)$ must be greater than a certain portion $(1-\gamma)$ of its asset, as in (40). Additionally, the bank's borrowing in the international interbank market cannot exceed a certain portion $\left(m_{F}\right)$ of the net value of domestic capital (total asset $b_{I, t}+b_{E, t}$ minus domestic liability $\left.d_{t}\right)$, as in (41).21)

19) I assume that banks can access unlimited finance at interbank rate $R_{t}^{I B}$ supplied by the central bank. Thus, by arbitrage, the wholesale bank rates are equal to the domestic interbank rate.

20) Note that I assume that a wholesale unit maximizes its utility rather than profit. This assumption is to consider this unit's role in managing the capital position in a more general form. FOCs derived from this setup are identical to the ones from profit maximization. See Iacoviello (2015) and Kang and Dao (2012) for instance. Additionally, the introduction of portfolio adjustment costs in the model helps to characterize real world financial frictions and derives the supply and demand of financial contracts. It also resolves the non-stationarity problem of the SOE model with incomplete financial markets. See Schmitt-Grohe and Uribe (2003) for details.

21) Similar assumptions on bank constraints are adopted by Iacoviello (2015) and Kang and Dao (2012). In practice, this type of capital control is regarded as the FX-related prudential measure (Ostry et al. 2011). 


$$
\begin{gathered}
d_{t}+Q_{t} l_{t}^{F} \leq \gamma\left(b_{I, t}+b_{E, t}\right) \\
Q_{t} l_{t}^{F} \leq m_{F}\left(b_{I, t}+b_{E, t}-d_{t}\right)
\end{gathered}
$$

The first-order conditions are banks' credit supply to households and entrepreneurs and demand for foreign bank liquidity.

$$
\begin{aligned}
& \frac{1-\phi_{d}\left(d_{t}-d_{t-1}\right)}{c_{B, t}}=\mathrm{E}_{t}\left[\frac{\beta_{B}}{c_{B, t+1}}\left(\frac{R_{t}^{I B}}{\pi_{t+1}}-\phi_{d}\left(d_{t+1}-d_{t}\right)\right)\right]-\lambda_{B, t}^{\prime}-\lambda_{B, t}^{\prime \prime} m_{F} \\
& \frac{1+\phi_{b I}\left(b_{I, t}-b_{I, t-1}\right)}{c_{B, t}}=\mathrm{E}_{t}\left[\frac{\beta_{B}}{c_{B, t+1}}\left(\frac{R_{t}^{I B}}{\pi_{t+1}}+\phi_{b I}\left(b_{I, t+1}-b_{I, t}\right)\right)\right]-\lambda_{B, t}^{\prime} \gamma-\lambda_{B, t}^{\prime \prime} m_{F} \\
& \frac{1+\phi_{b E}\left(b_{E, t}-b_{E, t-1}\right)}{c_{B, t}}=\mathrm{E}_{t}\left[\frac{\beta_{B}}{c_{B, t+1}}\left(\frac{R_{t}^{I B}}{\pi_{t+1}}+\phi_{b E}\left(b_{E, t+1}-b_{E, t}\right)\right)\right]-\lambda_{B, t}^{\prime} \gamma-\lambda_{B, t}^{\prime \prime} m_{F} \\
& \frac{1-\phi_{l}\left(l_{t}^{F}-l_{t-1}^{F}\right)}{c_{B, t}}=\mathrm{E}_{t}\left[\frac{\beta_{B}}{c_{B, t+1}}\left(Q_{t+1} \frac{R_{t}^{I B^{*}}}{\pi_{t+1}^{*}}-\phi_{l}\left(l_{t+1}^{F}-l_{t}^{F}\right)\right)\right]-\lambda_{B, t}^{\prime} Q_{t}-\lambda_{B, t}^{\prime \prime} Q_{t}
\end{aligned}
$$

where $\lambda_{B, t}^{\prime}$ and $\lambda_{B, t}^{\prime \prime}$ are Lagrangian multipliers on the capital requirement and the foreign debt constraints.

\subsection{Retail Branch}

Retail branches operate in a monopolistically competitive manner with the demand function given by (36) and (37). Each retail branch faces quadratic costs for adjusting its retail rates on loans and deposits. 
As for deposits, the retail unit of bank $j$ takes deposit $d_{t}(j)$ from patient households at the interest rate $R_{d, t}(j)$ and transfers them to the wholesale branch at rate $R_{t}^{I B}$. The retail branch sets deposit rates to maximize the profit from taking deposit over $R_{d, t}(j)$

$$
E_{0} \sum_{t=0}^{\infty} \Lambda_{0, t}^{B}\left[R_{t}^{I B} d_{t}(j)-R_{d, t}(j) d_{t}(j)-\frac{\kappa_{d}}{2}\left(\frac{R_{d, t}(j)}{R_{d, t-1}(j)}-1\right)^{2} R_{d, t} d_{t}\right]
$$

subject to demand (36). $\kappa_{d}$ is an adjustment cost parameter measuring the degree of stickiness for deposit rate and $\Lambda_{0, t}^{B}$ is the discount factor between time 0 and $t .{ }^{22)}$ The first-order condition for deposit rate determination is

$$
\begin{aligned}
-1-\varepsilon_{d}+\varepsilon_{d} \frac{R_{t}^{I B}}{R_{d, t}}-\kappa_{d}\left(\frac{R_{d, t}}{R_{d, t-1}}-1\right) \frac{R_{d, t}}{R_{d, t-1}} \\
+\beta_{P} \mathrm{E}_{t}\left[\frac{c_{P, t}}{c_{P, t+1}} \kappa_{d} \frac{d_{t+1}}{d_{t}}\left(\frac{R_{d, t+1}}{R_{d, t}}-1\right)\left(\frac{R_{d, t+1}}{R_{d, t}}\right)^{2}\right]=0
\end{aligned}
$$

The log-linearized version of deposit rate dynamics is drawn as

$$
\begin{aligned}
\widehat{R_{d, t}} & =\frac{1+\varepsilon_{d}}{1+\varepsilon_{d}+\left(1+\beta_{P}\right) \kappa_{d}} \widehat{R_{t}^{I B}} \\
& +\frac{\kappa_{d}}{1+\varepsilon_{d}+\left(1+\beta_{P}\right) \kappa_{d}} \widehat{R_{d, t-1}}+\frac{\beta_{P} \kappa_{d}}{1+\varepsilon_{d}+\left(1+\beta_{P}\right) \kappa_{d}} \mathrm{E}_{t} \widehat{R_{d, t+1}}
\end{aligned}
$$

This equation highlights how the retail unit sets deposit rate based on its past and future rate as well as the domestic interbank rate given the degree of adjustment costs and the intensity of competition in the deposit market.

22) Note that the bank is owned by patient households so that discount factor is taken from the problem of patient households. 
Similar to the deposit taking, the retail unit of bank $j$ receives wholesale loans $b_{s, t}^{H}(j)$ from the wholesale unit at the cost of $R_{t}^{I B}$ or $b_{s, t}^{F}(j)$ in the international interbank market at $R_{t}^{I B^{*}}$ for $s=I, E$, and sales them to impatient households and entrepreneurs. As in Brzoza-Brzezina and Makarski (2011), I assume that the bank is equipped with a technology of transforming each unit of credit taken in the domestic and international interbank (denominated in home currency) into a unit of retail loan contract.

$$
b_{s, t}(j)=b_{s, t}^{H}(j)+Q_{t} b_{s, t}^{F}(j)
$$

Formally, the profit maximization problem from loan issuance over $R_{b s, t}(j)$ can be stated as

$$
\mathrm{E}_{0} \sum_{t=0}^{\infty} \Lambda_{0, t}^{B}\left[R_{b s, t}(j) b_{s, t}(j)-R_{t}^{I B} b_{s, t}^{H}(j)-R_{t}^{I B^{*}} Q_{t} b_{s, t}^{F}(j)-\frac{\kappa_{b s}}{2}\left(\frac{R_{b s, t}(j)}{R_{b s, t-1}(j)}-1\right)^{2} R_{b s, t} b_{s, t}\right]
$$

subject to demand (37), and with a technology (49) for $s=I, E$. Solving the problem yields the first-order conditions for loan rates as (51) or their log-linearized expression as (52):

$$
\begin{aligned}
& 1-\varepsilon_{b s}+\varepsilon_{b s} \frac{m R_{t}^{I B}+(1-m) Q_{t} R_{t}^{I B^{*}}}{R_{b s, t}}-\kappa_{b s}\left(\frac{R_{b s, t}}{R_{b s, t-1}}-1\right) \frac{R_{b s, t}}{R_{b s, t-1}} \\
&+\beta_{P} \mathrm{E}_{t}\left[\frac{c_{P, t}}{c_{P, t+1}} \kappa_{b s} \frac{b_{s, t+1}}{b_{s, t}}\left(\frac{R_{b s, t+1}}{R_{b s, t}}-1\right)\left(\frac{R_{b s, t+1}}{R_{b s, t}}\right)^{2}\right]=0
\end{aligned}
$$




$$
\begin{aligned}
\widehat{R_{b s, t}}= & \underbrace{\frac{\varepsilon_{b s} m R^{I B}}{R_{b s}\left(\varepsilon_{b s}-1+\kappa_{b s}\left(1+\beta_{P}\right)\right)} \widehat{R_{t}^{I B}}}_{\text {domestic interbank rate }} \\
& +\underbrace{\frac{\varepsilon_{b s}(1-m) R^{I B^{*}}}{R_{b s}\left(\varepsilon_{b s}-1+\kappa_{b s}\left(1+\beta_{P}\right)\right)} \widehat{\kappa_{t}^{B^{*}}}}_{\text {foreign interbank rate }}+\underbrace{\frac{\varepsilon_{b s}(1-m) R^{I B^{*}}}{R_{b s}\left(\varepsilon_{b s}-1+\kappa_{b s}\left(1+\beta_{P}\right)\right)} \widehat{Q_{t}}}_{\text {real exchage rate }} \\
& +\underbrace{\frac{\beta_{P} \kappa_{b s}}{\varepsilon_{b s}-1+\kappa_{b s}\left(1+\beta_{P}\right)}}_{\text {past loan rate }} \widehat{R_{b s, t-1}} \mathrm{E}_{t} \widehat{R_{b s, t+1}}
\end{aligned}
$$

These equations indicate that banks set the loan rates based on the domestic and foreign interbank rates, their past and future rates and the real exchange rate, taking into account loan rate adjustment costs and the degree of market competition. The components associated with the foreign interbank rate plus the real exchange rate can be interpreted as the currency risk premiums created by capital flow (Hofmann, Shim and Shin 2017).23)

Additionally, solving banks' problem results in the uncovered interest parity (UIP) condition because banks have access to the international interbank market. The UIP shock $\left(\varepsilon_{e, t}\right.$ and its standard deviation $\left.\sigma_{e}\right)$ is assumed, as in Kollmann (2002), given the empirical findings on foreign exchange rates which have deviated strongly and persistently from the UIP condition after the end of Bretton Woods era.

$$
R_{t}^{I B}=R_{t}^{I B^{*}} E_{t}\left(\frac{e_{t+1} \varepsilon_{e, t}}{e_{t}}\right)
$$

where $e_{t}$ denotes the nominal exchange rate.

23) Note that in financial autarky, the dynamics of the loan rate are formulated based only on domestic interbank rate, and past and future rates. 


\subsection{The Foreign Sector and Monetary Policy}

Because I assume a SOE, the foreign economy is exogenous to the domestic economy and there is some flexibility in specifying the behavior of foreign variables, $\widehat{\pi_{t}^{*}}, \widehat{y_{t}^{*}}$ and $\widehat{R_{t+1}} \widehat{I B^{*}}$. To explore the dynamic relationships among the variables of the rest-of-the-world, approximated by the U.S. economy, I consider a structural VAR of three U.S. variables (ordered as listed above) as in Ghironi (2000).24) The data used for estimation is between 1980Q1 and 2008Q2 from Federal Reserve Economic Data (FRED), and the lag order is chosen as two quarters according to the various information criteria. The details of the set-up and estimation results are summarized in Appendix A-1.

As in common New Keynesian literature, a central bank determines the nominal policy rate according to a Taylor rule given by

$$
R_{t}^{I B}=\left(R_{t-1}^{I B}\right)^{\rho}\left[\left(R^{I B}\right)\left(\frac{\pi_{t}}{\pi}\right)^{\phi_{\pi}}\left(\frac{y_{t}}{y_{t-1}}\right)^{\phi_{y}}\right]^{1-\rho} \varepsilon_{R^{I B}, t}
$$

where $\rho, \phi_{\pi^{\prime}}$ and $\phi_{y}$ are weight parameters of the policy rate inertia, inflation, and output growth, respectively. $R^{I B}$ and $\pi$ stand for steady state value of policy rate and inflation. $\varepsilon_{R^{I B}, t}$ (with standard deviation $\sigma_{R^{I B}}$ ) represents monetary policy shocks which is white noise.

\subsection{Market Clearing}

The model is closed by specifying the market clearing conditions for the goods markets, the housing market, and the balance of payments. The market clearing condition in the final goods market is:

$$
y_{t}=c_{P, t}+c_{I, t}+c_{E, t}+c_{B, t}+i_{t}
$$

24) Another popular way to model the exogenous rest-of-the-world is to assume that foreign variables are $\mathrm{AR}$ processes. See Matheson (2010) for example. 
Next, the market clearing condition in the housing market is expressed as

$$
\bar{h}=h_{P, t}+h_{I, t}+h_{E, t}
$$

where $\bar{h}$ is fixed housing stock. The market clearing condition for balance of payment expressed in home currency is

$$
\frac{P_{t}^{H}}{P_{t}} y_{W, t}-y_{t}=Q_{t} \frac{R_{t-1}^{I B^{*}}}{\pi_{t}^{*}}\left(b_{I, t-1}^{F}+b_{E, t-1}^{F}+l_{t-1}^{F}\right)-Q_{t}\left(b_{I, t}^{F}+b_{E, t}^{F}+l_{t}^{F}\right)
$$

\section{Calibration and Estimation}

Data from Korea are used for the estimation because Korea is a typical small open economy where the financial system largely depends on the banking sector.25) I first calibrate some parameters that can be relatively easily obtained in the data and/or that have been well established in the previous literature. The rests are estimated with the Bayesian methods described in An and Schorfheide (2007).

\section{Calibrated Parameters}

The discount factors for each agent are within the range of the band interval (0.91, 0.99) according to Carroll and Samwick (1997). The discount factor of patient households $\left(\beta_{P}\right)$ is set to 0.99 to match the long-term average of the quarterly household deposit rate of $3.8 \%$ in the sample. I set the discount factors of impatient households, entrepreneurs and banks $\left(\beta_{I}, \beta_{E}\right.$ and $\left.\beta_{B}\right)$ as $0.95,0.95$, and 0.96, respectively, close to Kang and Dao (2012) to ensure positive financial

25) The Korean financial market shows high dependency on banking, but low portion of direct financing such as bonds and stocks. In particular, financing through banking sector occupied $90 \%$ and $54 \%$ for households and firms, respectively, whereas the portion of firms depending on the direct financing market was only $20 \%$ (as of 2008). For more details on the Korean financial institutions, see Ha and So (2013). 
Table 1: Calibrated Parameters

\begin{tabular}{|c|c|c|}
\hline Parameter & Description & Value \\
\hline$\beta_{P}$ & Patient Households' discount factor & 0.99 \\
\hline$\beta_{I}$ & Impatient Households' discount factor & 0.94 \\
\hline$\beta_{E}$ & Entrepreneurs' discount factor & 0.94 \\
\hline$\beta_{B}$ & Banks' discount factor & 0.96 \\
\hline$\mu$ & Capital share in the production function & 0.36 \\
\hline$\alpha$ & Patient/Impatient household ratio in the production function & 0.70 \\
\hline$v$ & Real estate share in the production function & 0.04 \\
\hline$\omega$ & Elasticity of substitution between home and foreign goods & 6.0 \\
\hline a & Share of home consumption component in the consumption index & 0.7 \\
\hline$\varepsilon_{d}$ & Elasticity of substitution between deposit & 1442.29 \\
\hline$\varepsilon_{b I}$ & Elasticity of substitution between loans for impatient households & 139.40 \\
\hline$\varepsilon_{b E}$ & Elasticity of substitution between loans for entrepreneurs & 211.48 \\
\hline$m$ & Share of home loan component in the loan index & 0.85 \\
\hline$m_{I}$ & LTV on loans to households & 0.5 \\
\hline$m_{E}$ & LTV on loans to entrepreneurs & 0.8 \\
\hline$m_{F}$ & Foreign capital regulation ratio & 0.5 \\
\hline$\gamma$ & Capital adequacy ratio & 0.85 \\
\hline$\delta$ & Capital depreciation rate & 0.025 \\
\hline$\eta$ & Weight on leisure & 1.01 \\
\hline$\rho$ & Policy rate inertia in Taylor rule & 0.75 \\
\hline$\phi_{y}$ & Weight on output in Taylor rule & 1.9 \\
\hline$\phi_{\pi}$ & Weight on inflation in Taylor rule & 0.4 \\
\hline
\end{tabular}

flow in the steady state.26) The technology parameters ( $\mu, v$ and $\alpha$ ) are chosen as $0.36,0.04$ and 0.70 on the basis of the data sample mean. The EOSs between deposits and loans $\left(\varepsilon_{d^{\prime}} \quad \varepsilon_{b I}\right.$ and $\left.\varepsilon_{b E}\right)$ are determined to match the steady-state markups of each rate on the policy rate. Notice that the EOS for deposit is set high because commercial banks in Korea typically determine deposit rates following the movement of policy rate. The LTV ratios on loans to households and entrepreneurs $\left(m_{I}\right.$ and $\left.m_{E}\right)$ and capital adequacy ratios $(\gamma$ and $\left.m_{F}\right)$ are calibrated to the long-term average of data obtained from bank business

26) Home banks borrow the funds from abroad only if the borrowing cost is cheaper than the domestic financing cost $\left(R^{I B^{*}}<R_{d}\right.$ ). For impatient households and entrepreneurs to borrow from banks, the interest rates that the banks charge should be low enough for borrowers, i.e. $\frac{1}{\beta_{I}}>R_{b I}$ and $\frac{1}{\beta_{E}}>R_{b E}$. 
analysis data and the financial information statistics system (FISIS). The parameters in Taylor rule $\rho, \phi_{y}$ and $\phi_{\pi}$ are set to $0.75,1.9$ and 0.4 according to the Bank of Korea's empirical estimates. The rest of the calibrated parameters are taken from Iacoviello (2005) and Gerali et al. (2010).

\section{Data and Estimation}

To estimate the remaining parameters, i.e., adjustment cost parameters and the standard error and autoregressive coefficients of all of the shocks, seven quarterly macroeconomic and financial time-series data are imported from the Economic Statistics System (ECOS) of the Bank of Korea. These data include the (seasonally adjusted) real GDP, CPI inflation, overnight call rate, bank loans to households and firms, and bank loan rates to households and firms.27) The sample period is chosen as 1999Q3 2014Q4 to correspond to a period of a homogeneous monetary policy regime.28) The data are detrended using an HP-filter with a smoothing parameter of 1,600. The detrended data are plotted in Figure 5.

I use the Metropolis-Hastings $(\mathrm{MH})$ algorithm to obtain the posterior distribution of the parameters by running 10 chains, with 100,000 draws each. Tables 2 and 3 report the summary statistics of prior and posterior distributions. Similar to Gerali et al. (2010) prior means of parameters controlling price stickiness $\left(\kappa_{P}^{H}\right.$ and $\left.\kappa_{P}^{F}\right)$ are set at 50, and those for interest rate adjustment costs $\left(\kappa_{d}, \kappa_{b I}\right.$ and $\left.\kappa_{b E}\right)$ are set at 10 . The prior mean for the capital adjustment cost $\left(\kappa_{K}\right)$ is set at 2.5. Following Iacoviello (2015) and Kang and Dao (2012), I also set the prior means of banks' portfolio adjustment cost parameters $\left(\phi_{d^{\prime}}, \phi_{b I}\right.$ and $\left.\phi_{b E}\right)$ at 0.25 .29$)$ I impose priors for the standard deviations of the above

27) There are seven exogenous shocks in the model. As in the usual practice for the estimation, I use as many observable variables as shocks.

28) The Bank of Korea has been adopting inflation targeting since 1999 and manipulates short-term interest rates (overnight call rate before February 2008, base rate after February 2008) as a policy instrument.

29) These parameters are linked to the elasticity of loan and deposit supplies. The derivatives of loan adjustment cost functions, for instance, can be written as $\frac{d_{\xi_{b s}}}{d b_{s}}=\phi_{b s}\left(b_{s, t}-b_{s, t-1)}\right.$. This situation indicates that when quarterly 
Figure 5: Data Used in Estimation

A. GDP

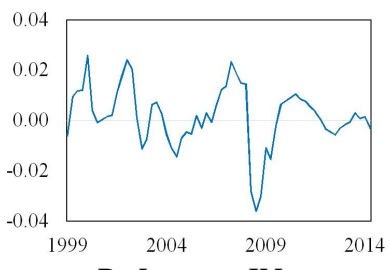

D. Loan to IHs
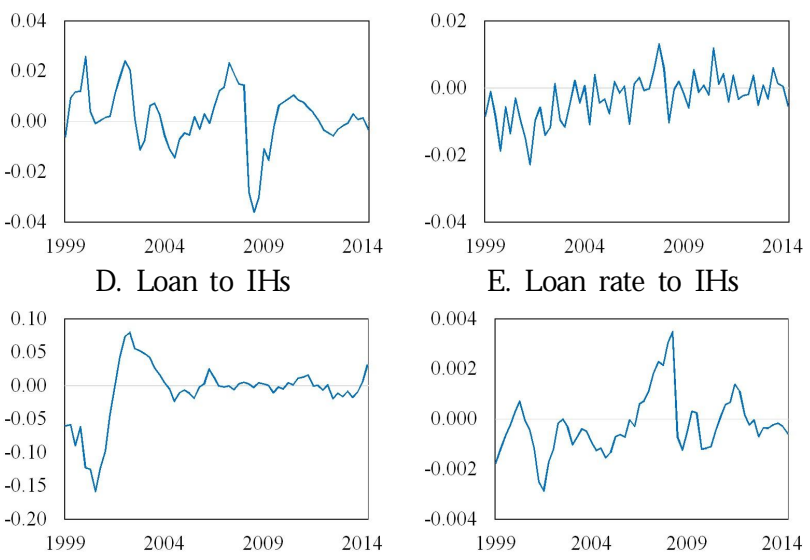

E. Loan rate to IHs

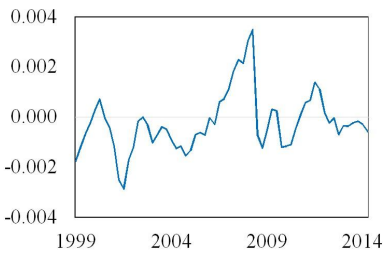

G. Loan rate to Es

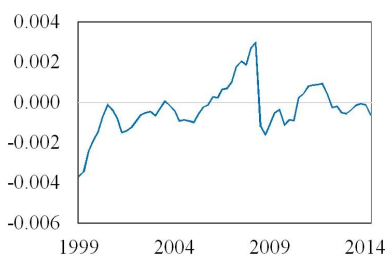

C. Overnight call rate

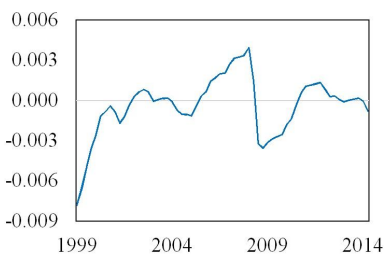

F. Loan to Es

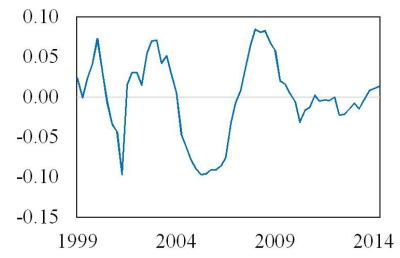




\section{$31 \quad$ BOK Working Paper No. 2017-33}

Table 2: Prior and Posterior Distribution of Parameters:

Structural Parameters

\begin{tabular}{|c|c|c|c|c|c|c|}
\hline \multirow{2}{*}{ Parameter } & \multicolumn{3}{|c|}{ Prior Distribution } & \multicolumn{3}{|c|}{ Posterior Distribution } \\
\hline & Distribution & Mean & St.dev. & Median & Mean & St.dev \\
\hline$\kappa_{d}$ & Gamma & 10.0 & 2.5 & 4.29 & 4.30 & 0.130 \\
\hline$\kappa_{b I}$ & Gamma & 10.0 & 2.5 & 22.65 & 23.34 & 0.506 \\
\hline$\kappa_{b E}$ & Gamma & 10.0 & 2.5 & 7.51 & 7.66 & 0.585 \\
\hline$\phi_{d}$ & Beta & 0.25 & 0.1 & 0.24 & 0.24 & 0.001 \\
\hline$\phi_{b I}$ & Beta & 0.25 & 0.1 & 0.26 & 0.26 & 0.001 \\
\hline$\phi_{b E}$ & Beta & 0.25 & 0.1 & 0.25 & 0.25 & 0.001 \\
\hline$\phi_{l}$ & Beta & 0.25 & 0.1 & 0.24 & 0.24 & 0.001 \\
\hline$\kappa_{p}^{H}$ & Gamma & 50.0 & 10.0 & 41.74 & 41.91 & 2.765 \\
\hline$\kappa_{p}^{F}$ & Gamma & 50.0 & 10.0 & 44.70 & 45.23 & 0.875 \\
\hline$\kappa_{K}$ & Gamma & 2.5 & 1.0 & 1.60 & 1.60 & 0.044 \\
\hline
\end{tabular}

Table 3: Prior and Posterior Distribution of Parameters: Exogenous Processes

\begin{tabular}{|c|c|c|c|c|c|c|}
\hline \multirow{2}{*}{ Parameter } & \multicolumn{3}{|c|}{ Prior Distribution } & \multicolumn{3}{|c|}{ Posterior Distribution } \\
\hline & Distribution & Mean & St.dev. & Median & Mean & St.dev. \\
\hline \multicolumn{7}{|c|}{$A R$ coefficients } \\
\hline$\theta_{A}$ & Gamma & 0.8 & 0.01 & 0.80 & 0.80 & 0.010 \\
\hline$\theta_{j}$ & Gamma & 0.8 & 0.01 & 0.81 & 0.81 & 0.010 \\
\hline \multicolumn{7}{|c|}{ Standard deviations } \\
\hline$\sigma_{A}$ & Inv. Gamma & 0.01 & 0.05 & 0.01 & 0.01 & 0.005 \\
\hline$\sigma_{j}$ & Inv. Gamma & 0.01 & 0.05 & 0.24 & 0.25 & 0.034 \\
\hline$\sigma_{R^{I B}}$ & Inv. Gamma & 0.01 & 0.05 & 0.04 & 0.04 & 0.003 \\
\hline$\sigma_{e}$ & Inv. Gamma & 0.01 & 0.05 & 0.06 & 0.06 & 0.006 \\
\hline$\sigma_{R^{B^{*}}}$ & Inv. Gamma & 0.01 & 0.05 & 0.04 & 0.04 & 0.004 \\
\hline$\sigma_{y^{*}}$ & Inv. Gamma & 0.01 & 0.05 & 0.02 & 0.02 & 0.002 \\
\hline$\sigma_{\pi^{*}}$ & Inv. Gamma & 0.01 & 0.05 & 0.05 & 0.05 & 0.005 \\
\hline
\end{tabular}




\section{Empirical Fit of the Model}

The empirical fit of the model is first assessed by the comparison between the steady state values and the long-term average of variables (1998Q 1 2014Q4). Table 4 summarizes the steady state values of the key macroeconomic variables calculated from the model, including consumption, investment and the interest rate, and compares them with observed data. Overall, the steady state ratios of main variables (e.g., the ratio of macroeconomic variables to GDP) are largely similar to the actual data, which implies that the parameters in the model represent the reality of the Korean economy.30)

As an additional test of the reliability of model, I assess the model in fitting actual data that are not used in the model estimation. This exercise is performed to address the critique that the DSGE model performs well in fitting the data in the sample but is poor at fitting the rest of the data (e.g., Iacoviello, 2015). Figure 6 contrasts the actual data for consumption, deposit, deposit rate (from ECOS), and housing price (from the Kookmin bank housing price index) with the model simulated series. Overall, the model's smoothed estimates trace well their data counterparts. In furtherance of a similar idea, the unconditional standard deviations of the observable variables at the posterior mean are compared with the standard deviations of actual data series. The difference between the two standard deviations (std. of observable variable in the model std. of actual data) by main variable is less than 0.03 (consumption: 0.00 , investment: 0.01 , deposit: -0.03 , housing price: 0.00 ).

\section{The Transmission Mechanism of MP Shocks}

As in existing studies, the model suggests several channels that explain the transmission of local MP shocks: the real rate, nominal debt, financial

30) Steady state ratios of banks' deposits and loans to GDP are smaller than the ratios of their data counterparts. This discrepancy may be attributed to strong assumptions on the banks' balance sheets. For instance, banks' reserves, and security and cash holdings are not considered in the model. 
Table 4: Steady State Ration of the Model

$\frac{c_{P}+c_{I}}{y}$

Households' consumption to GDP

0.68

0.68

$\frac{i}{y} \quad$ Facility investment to GDP

0.08

0.09

$\frac{b_{E}}{y} \quad$ Loans to entrepreneur to GDP

1.02

1.12

$\frac{b_{I}}{y} \quad$ Loans to household to GDP

1.55

0.88

$\frac{d}{y} \quad$ Deposit to GDP

1.80

2.59

$\frac{h}{y} \quad$ Housing stock to GDP

1.98

1.77

$\frac{k}{y}$

Capital stock to GDP

3.35

3.78

Figure 6: Historical Decomposition of Model Series and Actual Data

A. Consumption

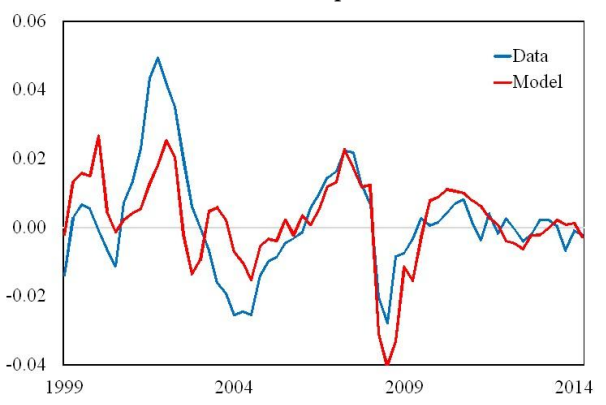

C. Deposit rate

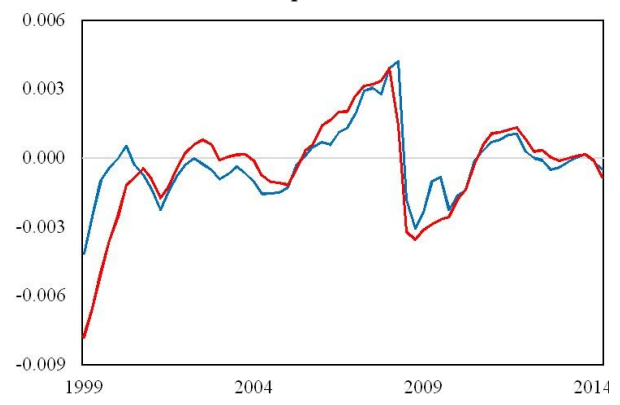

B. Deposit

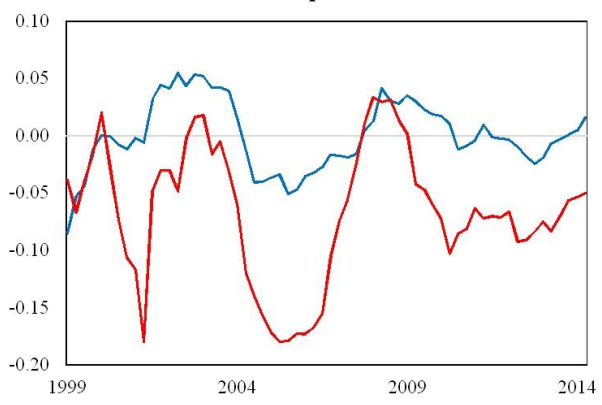

D. Housing price

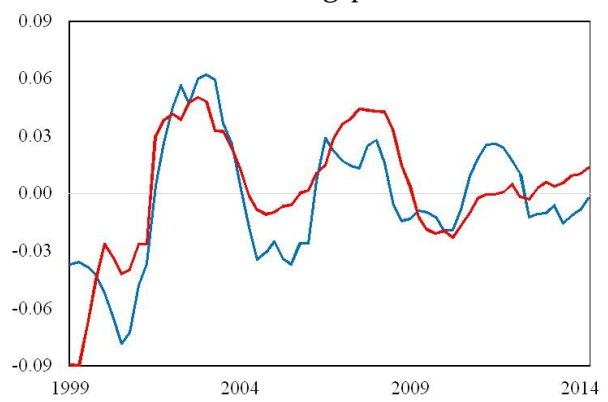

Notes: All of the variables are expressed as log deviations from the HP-filter trend. 
accelerator, bank attenuator and bank lending channel (studied mainly in closed economy models; see Iacoviello, 2005; Gerali et al., 2010; Van den Heuvel, 2008 for instance).31) Additionally, foreign interest rate shocks can be migrated to the SOE's financial market by adjusting the domestic interbank rate according to the interest-parity condition or by adjusting the bank's interest rate setting with consideration for the domestic and international interbank rate (Obstfeld, 2014; Passari and Rey, 2015).

In this section, I study how banking sector openness alters the transmission mechanism of home and foreign MP shocks, particularly focusing on the channels related to the banking sector.

\section{Transmission of Home MP Shock}

The introduction of banking sector openness attenuates the impulse responses to an unanticipated contractionary MP shock via the following two channels:32)

First, the effects of domestic policy rate adjustment are transmitted less to Ioan rates (i.e., foreign interest rate channe). In financial autarky, the banks can take loans only domestically at the cost of $R_{t}^{I B}$, and thus the retail rates for loans are set based on the mark-up over the domestic interbank rate (Gerali et al., 2010; $\mathrm{Ha}$ and So, 2013). By contrast, if banks can access the international

31) In response to a policy rate rise, real rates increase due to the presence of price stickiness, thus leading to a fall in the aggregate spending of households and firms (real rate channel). A fall in the price caused by a policy rate increase raises the real cost of borrowers' current debt obligation and the real remuneration on saver's deposits (nominal debt channel ). On a contractionary MP shock, banks cut their loans to constrained borrowers due to the decline of the net present value of tomorrow's collateral, thereby creating an additional downward pressure on aggregate demand (financial accelerator channel). Bank presence influences the impact of MP shocks on the economy. However, the overall effect is not clear. In response to a negative shock to the bank capital/asset ratio caused by contractions of bank deposit, banks tighten their lending standards, which worsen credit conditions (bank lending channel). Due to the presence of a bank's market power, banks raise the remuneration of deposits and the cost of loans by a lower amount following the policy rate increase, and thus financial intermediation moderates the overall effects listed above (bank attenuator channel).

32) As proposed by Gerali et al. (2010), domestic MP transmission may also be attenuated due to the presence of monopoly power in the deposit and loan markets. I provide the analysis of the effect of market power in the banking industries in Appendix A-2. Overall, the attenuating effect of bank globalization is comparable to the bank attenuator effect. 
Table 5: Decomposition of MP Transmission Channels

\begin{tabular}{c|c|cc} 
& Baseline Model & \multicolumn{2}{|c}{ Alternative Models } \\
\cline { 3 - 4 } & $(\mathrm{BM})$ & $(\mathrm{AM} 1)$ & (AM2) \\
Foreign liquidity channel (A) & 0 & 0 & $\times$ \\
\hline Foreign interest rate channel (B) & 0 & $\times$ & (B) \\
\hline Identify & & (A)
\end{tabular}

Notes: $\bigcirc$-Existing in the model, $x$-Not existing in the model.

interbank market to import wholesale loan accounts at rate $R_{t}^{I B^{*}}$, they can set loan rates, taking into account not only domestic interbank rates but foreign interbank rates as well as real exchange rate. Loan rates under banking sector openness are therefore affected by domestic MP shocks only up to the portion for which banks rely on the domestic borrowers. In addition, the real exchange rate appreciates (i.e. declines) in response to a contractionary domestic monetary shock. This situation reduces the strength of the real rate effect (depression of consumption and investment triggered by real rates increases) and the financial accelerator effect (downward pressure on aggregate demand created by the contraction in bank loans toconstrained borrowers' net present value of collaterals).

Second, the global liquidity management of SOE banks can insulate credit supply from domestic monetary shock as in Cetorelli and Goldberg (i.e., foreign liquidity channel). An increase in policy rate has negative impact on output and, subsequently, on household labor income. A fall in income leads to contractions in deposits, thereby tightening banks' balance sheet conditions. Under financial autarky, the shock is transmitted to the banks' asset side. Banks that cannot substitute liabilities with other external funding sources must reduce their assets (or loans) against the change of the balance sheet position. Banks' adjustment of lending activity puts additional strain on aggregate demand because households and firms depend on bank credit to run their activities. Meanwhile, in a model 
Figure 7: Impulse Response to Contractionary Domestic MP Shock (25bp)

A. Output

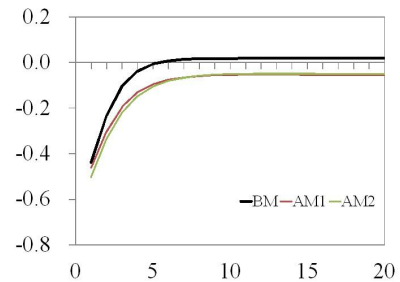

D. Loan to IHs

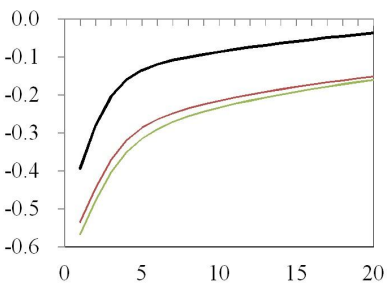

G. Interest for IHs Loan

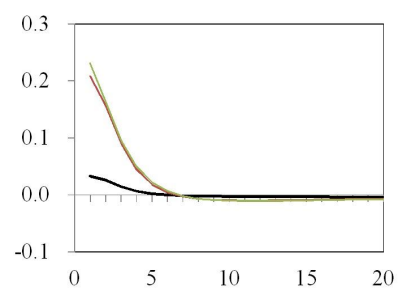

B. Housing Price

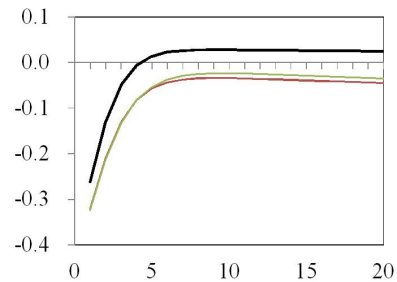

E. Loan to Es

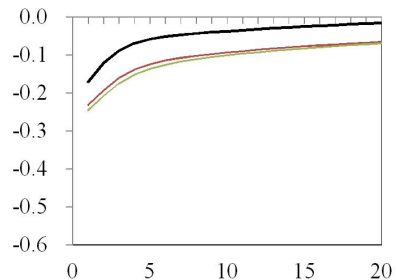

H. Interest for Es Loan

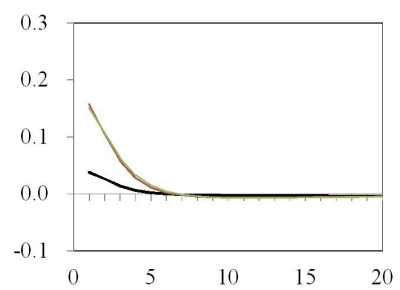

C. Loan from Foreign

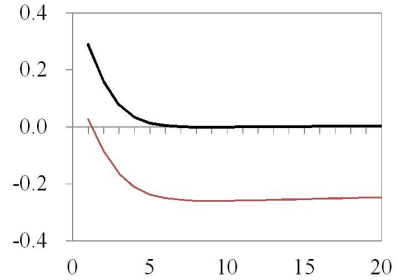

F. Deposit

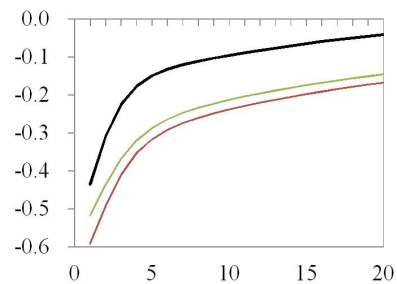

I. Interest for Deposit

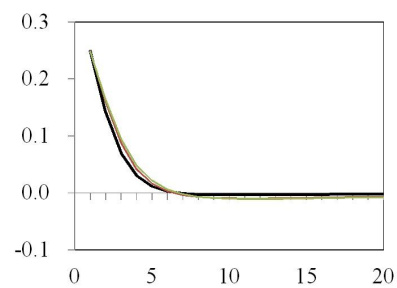

Notes: 1. BM: Baseline model,

AM1: Alternative model 1(no foreign interest rate channel),

AM2: Alternative model 2(AM1 + no foreign liquidity channel)

2. IHs: Impatient households, Es: Entrepreneurs

3. Horizontal axis: Quarters from the shock;

Vertical axis: Percentage deviation from steady state.

with bank globalization, globalized local banks can accommodate the shock. Foreign liquidity that banks raise in the international interbank market plays a role as a buffer for absorbing or mitigating the negative MP impact on the balance sheet.

To understand which of the two effects prevails when international banking is introduced and to quantitatively assess the relevance of the different channels in shaping the dynamic properties of the economy, I compare the responses of the 
baseline model examined in the previous section with those of the alternative models where I shut down the transmission channels of MP one by one against the same contractionary monetary shocks (25 basis points increase): (i) only the foreign interest rate channel is blocked in AMI and (ii) both the foreign interest rate channel and foreign liquidity channel are blocked in AM2. However, all channels work with significance in BM as previously assumed. To be specific, the foreign liquidity channel is blocked if bank borrowing from abroad is set to zero $\left(l_{t}^{F}=0\right)$. Similarly, to shut down the foreign interest rate channel, we may assume that bank can collect and sell loan accounts only in their home countries $\left(b_{s, t}=b_{s, t}^{H}\right.$ for $\left.s=I, E\right)$. Table 5 briefly describes the strategy of verifying the direction and strength of each channel by comparing the results between each model in response to the same MP shocks.

Figure 7 exhibits the impacts of policy tightening on key macroeconomic and financial variables through each transmission channel, and Table 6 summarizes the average impulse response of key variables in the first year. Parameter values are set at the estimated posterior mean. The responses of BM (black line) are standard. Deposit and loan rates rise following policy rate increases. This change in bank rates leads to housing price declines $(-0.11 \%$ in the first year), which reduces the net present value of tomorrow's collateral. Consequently, the amount of loans decreases, and the output $(-0.20 \%)$ and inflation $(-0.04 \%)$ fall because the productive sector of the economy relies on bank credit.33)

The role of bank globalization begins to appear when we consider the responses of the AM1 (red line) and the AM2 (green line), which block the foreign interest rate channel and the foreign liquidity channel, respectively. The main result that emerges from comparing $A M 1$ and $A M 2$ with the baseline model is that the introduction of international banking attenuates the effects of contractionary MP shocks.

First, when comparing BM and AM1 with regard to the responses of each

33) For your reference, on the same policy shock, output and inflation decrease by $0.18 \%$ and $0.05 \%$, respectively, according to the Bank of Korea's BOKDSGE model. 


\section{Table 6: Comparison of the Impacts of MP Tightening (25bp) through Each Channel}

\begin{tabular}{c|ccccccc|c} 
& \multicolumn{1}{c|}{$y$} & $R_{b I}$ & $R_{b E}$ & $R_{d}$ & $b_{I}$ & $b_{E}$ & $d$ & MP shocks \\
\hline BM & -0.20 & 0.02 & 0.02 & 0.12 & -0.26 & -0.11 & -0.29 & - \\
AM1 & -0.27 & 0.13 & 0.09 & 0.13 & -0.42 & -0.18 & -0.46 & - \\
AM2 & -0.30 & 0.13 & 0.09 & 0.14 & -0.45 & -0.20 & -0.41 & - \\
\hline $\begin{array}{l}\text { Foreign interest rate } \\
\text { channel (BM-AM1) }\end{array}$ & 0.07 & -0.11 & -0.07 & -0.01 & 0.16 & 0.07 & 0.18 & Weakened \\
$\begin{array}{l}\text { Foreign liquidity } \\
\text { channel (AM1-AM2) }\end{array}$ & 0.03 & -0.01 & -0.01 & -0.01 & 0.03 & 0.01 & -0.05 & Weakened \\
\hline
\end{tabular}

Notes: Average impulse responses in the first year.

macroeconomic and financial variable to the MP tightening shocks by $25 \mathrm{bp}$, the responses of loan rates are smaller in the former model than the latter with a gap of $0.11 \% \mathrm{p}$ in the loan rate to impatient households and a gap of $0.07 \% \mathrm{p}$ in the loan rate to entrepreneurs, on average, during the first year after shock. This smaller response of loan rates induces a smaller change in loan and deposit demands, thus reducing output by a lower amount (0.07\%p less). Consumption and investment also react less in BM than in AM1 by $0.07 \% \mathrm{p}$ and $0.04 \% \mathrm{p}$ respectively. This result indicates that MP shocks are weakened in international banking intermediation, particularly by the existence of foreign interest rate channels consistent with theoretical direction.

Second, according to the comparison between $A M 1$ and $A M 2$ regarding responses to MP shocks, although deposits shrink more in AM1 than in AM2 against policy rate increases, smaller loan responses are seen in the former than in the latter, with a gap of $0.03 \%$ in loans to impatient households and a gap of $0.01 \% \mathrm{p}$ in loans to entrepreneurs. Consequently, output drops by less than $0.03 \% \mathrm{p}$ in AM1 compared to AM2. The responses of the variables confirm the existence of a foreign liquidity channel in line with much of the available 
literature (e.g., Cetorelli and Goldberg, 2012, Morais et al. 2017, etc).

The findings verify that the attenuation effect of bank globalization after an MP shock is mainly due to the foreign interest rate channel, which dampens the response of loan rates, thereby hindering the decline of loans and aggregate demand. The impact of the foreign liquidity effect is limited, reflecting the opposite and mutually offsetting effects on the demand and supply of foreign liquidity. Due to foreign debt constraint, the amount of net domestic bank capital determines the availability of foreign capital, thus limiting the foreign liquidity channel if the bank deposit shrinks more than the loan on a negative MP shock.

\section{Transmission of Foreign MP Shock}

International banking intensifies the transmission of foreign MP shocks to domestic market rates, particularly loan rates. Conventional open economy models assume that foreign monetary shocks affect short-term rates in SOEs following the interest-parity relationship, and inevitably influence other market rates that are set based on the movement of the short-term rate. Another channel of international monetary spillover to domestic market rates is the policy response of a SOE central bank to the inflationary pressure caused by exchange rate pass-through (e.g., Aoki, Benigno, and Kiyotaki, 2016). Responding to a foreign monetary tightening shock, the real exchange rate depreciates (i.e. rises) while raising CPI inflation. Consequently, a central bank who concerns the inflation sets the policy rate higher, leading to an increase in market rates. Both channels implicitly assume the indirect transmission by the adjustment of domestic policy rate (referred to as indirect international monetary transmission).

In addition to the aforementioned indirect international monetary transmission channels, local banks' international banking induces bank rates to react directly to the change in foreign MP shocks. It is because local banks that import foreign intermediate loan contracts determine their loan rates by considering the cost of raising funds on both domestic and international interbank markets 
Figure 8: Impulse Response to Contractionary Foreign MP Shock (25bp)

A. Output

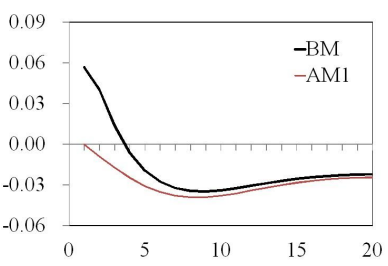

D. Loan to IHs

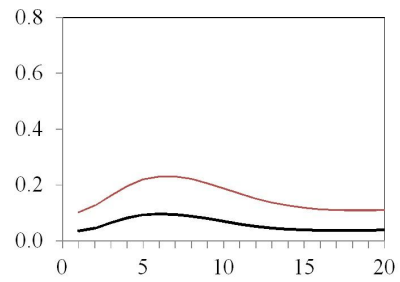

G. Interest for IHs Loan

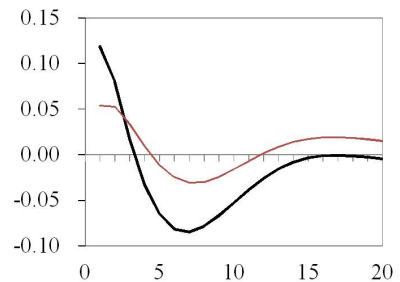

B. Overnight Rate

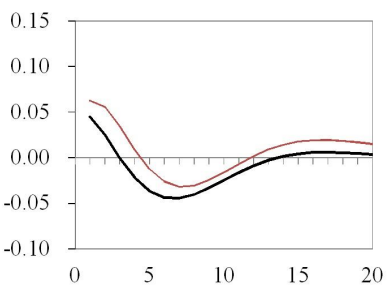

E. Loan to Es

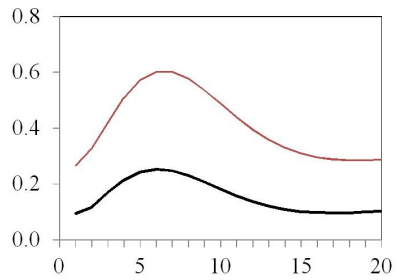

H. Interest for Es Loan

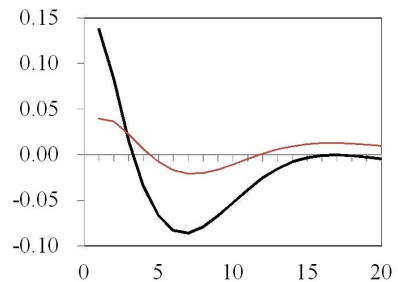

C. Real Exchange Rate

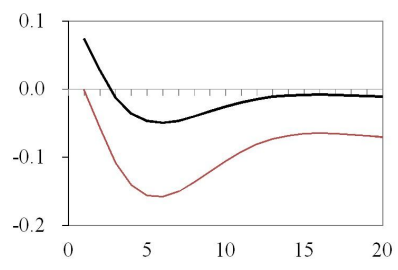

F. Deposit

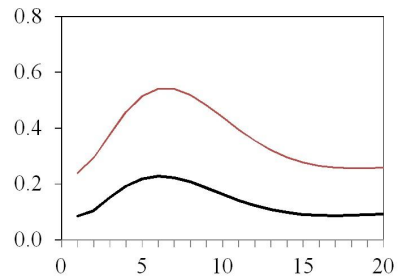

I. Interest for Deposit

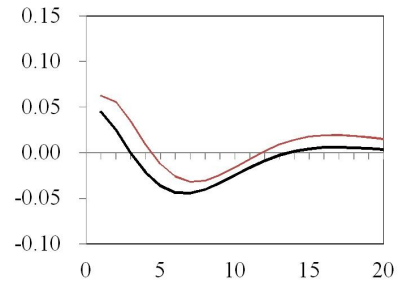

Notes: 1. BM: Baseline model,

AM1: Alternative model 1(no foreign interest rate channel),

2. IHs: Impatient households, Es: Entrepreneurs

3. Horizontal axis: Quarters from the shock;

Vertical axis: Percentage deviation from steady state.

(referred to as direct international monetary transmission). The effect of foreign monetary shocks through this direct channel is intensified by the response of real exchange rate (i.e. depreciation in the case of a rise in foreign interest rates), which is another important determinant of local loan rates, similar to H ofmann, Shim and Shin (2017).

The mechanism of international monetary transmission is studied by looking at the impulse responses of $B M$ and $A M 1$, as illustrated in the previous section. 
Table 7: Comparison of the Impacts of Foreign MP Tightening (25bp)

\begin{tabular}{|c|c|c|c|c|c|c|c|}
\hline & $R^{I B}$ & $R_{d}$ & $R_{b I}$ & $R_{b E}$ & $R_{d}-R^{I B}$ & $R_{b I}-R^{I B}$ & $R_{b E}-R^{I B}$ \\
\hline AM1 & \multicolumn{3}{|c|}{ (Indirect transmission) } & 0.03 & \multicolumn{3}{|c|}{ (Frictions) } \\
\hline BM & $\begin{array}{r}0.01 \\
(1 \\
\text { tran }\end{array}$ & $\begin{array}{l}0.01 \\
\text { ect } \\
\text { sion) }\end{array}$ & $\begin{array}{c}0.05 \\
\text { (Indir } \\
\text { trans }\end{array}$ & $\begin{array}{l}0.05 \\
\text { Direct } \\
\text { sion) }\end{array}$ & -0.0000 & $\begin{array}{c}0.0335 \\
\text { (Frictions) }\end{array}$ & 0.0381 \\
\hline
\end{tabular}

Notes: Average impulse responses in the first year.

I compare only the responses from BM with those from AM1 to focus on the direct impact of foreign MP shocks on the domestic loan rates. Note that, for simplicity, foreign liquidity is not considered in modeling foreign sector. See Section 3.7 and Appendix A-1 further.

Figure 8 shows the impulse responses from an unanticipated 25bp increase in the foreign policy rate. Table 7 summarizes the average impulse response of key variables in the first year.

Overall, in the two models, the response of domestic interest rates, including policy rates, is positive against negative foreign MP shock and leads to a fall in output. However, compared to a model lacking a foreign interest rate channel (AM 1, red line), the interest rates, particularly loan rates, in the baseline model (black line) show more sensitive responsiveness to foreign monetary surprises. To gain intuition from the results, it is useful to discuss how local banks' international banking modifies the international transmission channels of foreign MP shocks.

In $A M 1$, loan rates are determined based on the domestic policy rate (RIB) and past and future rates, as in Gerali et al. (2010). The only channel through which foreign interest rates can affect the movement of loan rates is that of a SOE's policy rate adjustment $(0.04 \% \mathrm{p}$ on average in the first year) after a foreign shock. As discussed above, this policy rate change is triggered by interest-parity condition and exchange rate pass-through. However, due to the 
presence of frictions between policy rates and loan rates in the models, this transmission channel may exert limited impacts on loan rate movement. The responses of loan rates to impatient households and entrepreneurs are smaller than those of domestic policy rates by $0.003 \% \mathrm{p}$ and $0.014 \%$, respectively.

However, when we introduce a banking sector that imports foreign loan accounts $(\mathrm{BM})$, loan rates are set based on both domestic $\left(R^{I B}\right)$ and foreign $\left(R^{I B^{*}}\right)$ policy rates, as shown in equations (51) and (52). Additionally, the real exchange rate depreciates (i.e. rises) in response to a contractionary foreign monetary shock. This situation adds a stronger propagation mechanism: in addtion to indirect transmission channel through policy rate adjustment $(0.01 \% p$ on average in the first year), foreign monetary shocks can also directly influence the loan rates in this process. Thus, loan rates respond even more $(0.05 \% \mathrm{p}$ in loan rates to entrepreneurs and impatient households) than domestic policy rates. However, as in Aoki, Benigno, and Kiyotaki (2016), output can initially increase as net export goes up against a contractionary international monetary shock, following the depreciation of real exchange rate. Output responds negatively after one year as the shocks also pass through to domestic interest rates. On the other hand, loans to households and firms temporarily increase due to a rise in exports caused by exchange rate pass-through as well as a decline in relative cost for raising liquidity at home.

For ease of comparison, each panel in Figure 9 plots the joint response of both loan rates and domestic policy rates to a foreign monetary shock. In Panel A, which describes the responses of variables in $A M 1$, loan rates react to foreign monetary surprises by a lower amount than to the domestic policy rate for the initial four quarters. However, for BM in Panel B, loan rates respond more to a contractionary foreign MP shock than do domestic policy rates for the period. Similar results are found in Morais et al. (2017) that foreign monetary shocks can affect local rates significantly because of globalized banks' reach-for-yield incentives. 
Figure 9: Comparison of Impulse Responses of Interest Rates to Foreign MP Shock (25bp)

A. AMI

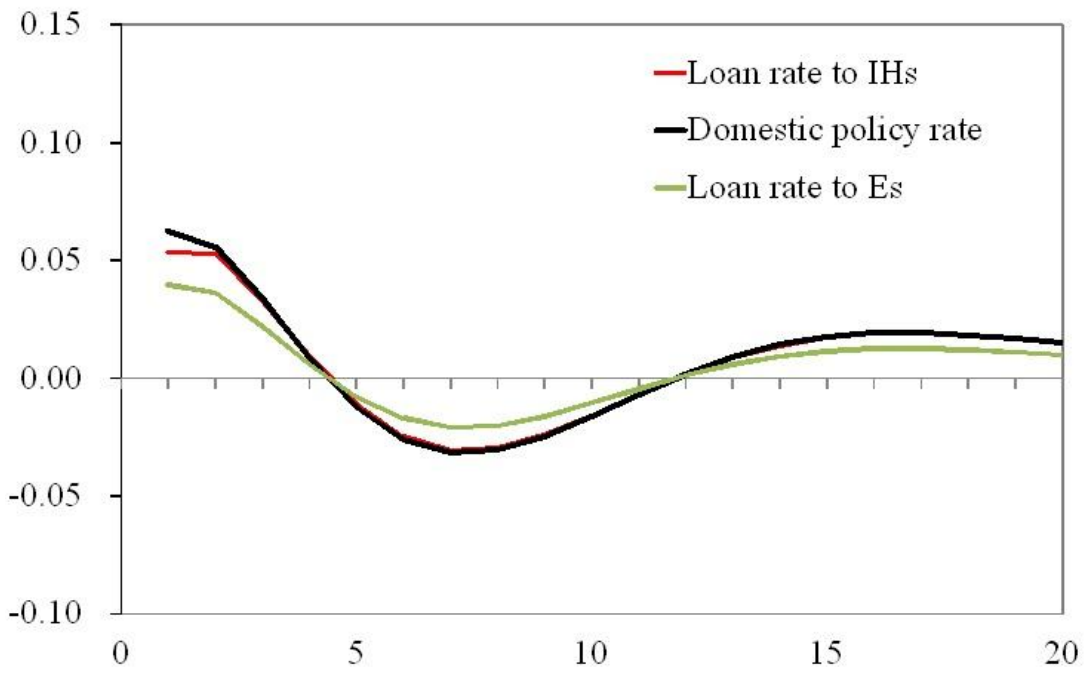

B. BM

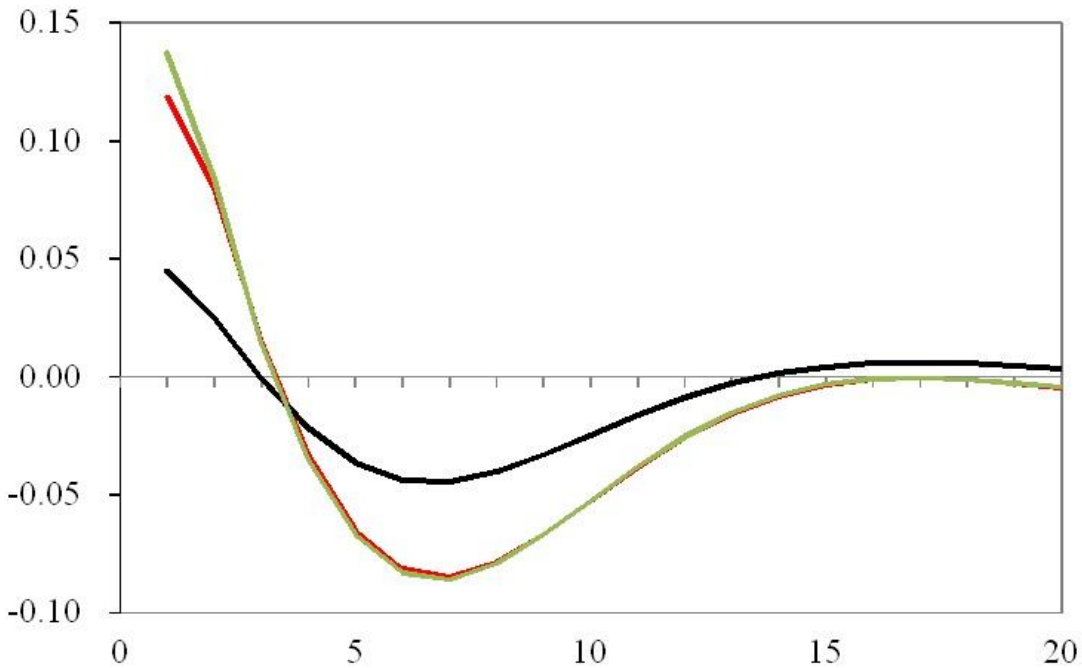

Notes: 1. BM: Baseline model,

AM1: Alternative model 1(no foreign interest rate channel)

2. IHs: Impatient households, Es: Entrepreneurs

3. Horizontal axis: Quarters from the shock; Vertical axis: Percentage deviation from steady state. 


\section{Conclusions}

This paper studies the conventional topic about the transmission of local and international monetary shocks in SOEs, but sheds light on how well domestic and international MP shocks propagate through banking sectors and whether such transmission channels are altered by bank globalization. To that end, the model in this paper is a first attempt to investigate the channels through which international banking influences MP transmission under the general equilibrium framework. Furthermore, to disentangle the complex workings of bank globalization, I introduce two common sets of bank globalization factors in the model: imported loan contracts and foreign operating funds.

The study's findings are twofold. First, bank globalization attenuates MP transmission. Compared to the financial autarky model, loan rates increase less in response to a negative monetary shock, thereby exerting a foreign interest rate effect. This channel alleviates the strength of the real rate effect and financial accelerator effect. However, through a foreign liquidity channel, banks that face capital requirement constraints can also avoid negative policy effects to some extent by expanding credit through foreign bank capital. The impulse response of output to a contractionary MP shock (25 basis point increase in policy rate) declines by $0.07 \%$ p due to the foreign interest rate effect and by $0.03 \%$ p due to the foreign liquidity effect in the first year, respectively. Second, international banking amplifies international monetary spillovers. In addition to the indirect channels through domestic policy rate adjustment, international banking activities directly link foreign interbank rates and domestic loan rates. Thus, compared to the model without bank globalization, the impulse response of loan rates to foreign MP shock shows that the direct international monetary transmission channel accounts for approximately $0.03 \sim 0.04 \%$ p of loan rate responses.

The results indicate that policy effects are not always driven in the ways that central banks intend under the globalized banking system. In my analysis, transmission of home MP shocks is attenuated whereas international monetary transmission is substantially intensified by bank globalization. Central bankers are 


\section{$45 \quad$ BOK Working Paper No. 2017-33}

confronted with an expanded need for taking into consideration the role of international banking intermediation in MP transmission when determining the scale and timing of policies. 


\section{References}

An, S., Schorfheide, F. (2007). Bayesian analysis of DSGE models. Econometric Reviews, 26(2-4), 113-172.

Aoki, K., Benigno, G., and Kiyotaki, N. (2016). Monetary and Financial Policies in Emerging Markets. Mimeo. Princeton University

Bernanke, B. (2007). Globalization and Monetary Policy. Speech at the Fourth Economic Summit, Stanford Institute for Economic Policy Research.

Bernanke, B. S., Gertler, M. (1995). Inside the black box: The credit channel of monetary policy transmission. The Journal of Economic Perspectives, 9(4), 27-48.

Bjørnland, H. C. (2009). Monetary policy and exchange rate overshooting: Dornbusch was right after all. Journal of International Economics 79, 6477.

Blanchard, O. J., and Fischer, S. (1989). Lectures on Macroeconomics. Cambridge: MIT Press.

Brooks, S. P., and Gelman, A. (1998). General methods for monitoring convergence of iterative simulations. Journal of computational and graphical statistics, 7(4), 434-455.

Bruno, V., and Shin, H. S. (2015). Capital flows and the risk-taking channel of monetary policy. Journal of Monetary Economics, 71, 119-132.

Brzoza-Brzezina, M., Makarski, K. (2011). Credit crunch in a small open economy. Journal of International Money and Finance, 30(7), 1406-1428.

Carroll, C. D., Samwick, A. A. (1997). The nature of precautionary wealth. Journal of monetary Economics, 40(1), 41-72.

Cetorelli, N., Goldberg, L. S. (2012). Banking globalization and monetary transmission. The Journal of Finance, 67(5), 1811-1843.

Devereux, M. B., Yu, C. (2014). International Financial Integration and Crisis Contagion. NBER Working Papers No. w20526. 
Freixas, X., and Rochet, J. C. (1997). Microeconomics of banking (Vol. 2). Cambridge, MA: MIT press.

Gali, J., Monacelli, T. (2005). Monetary policy and exchange rate volatility in a small open economy. The Review of Economic Studies, 72(3), 707-734.

Gerali, A., Neri, S., Sessa, L., Signoretti, F.M. (2010). Credit and banking in a DSGE model of the euro area. Journal of Money, Credit, and Banking, 42 (s1), 107141.

Gertler, M., Karadi, P. (2011). A model of unconventional monetary policy. Journal of Monetary Economics, 58 (1), 1734.

Gertler, M., Karadi, P. (2015). Monetary Policy Surprises, Credit Costs, and Economic Activity. American Economic Journal: Macroeconomics, 7(1), 44-76.

Gertler, M., Kiyotaki, N. (2010). Financial intermediation and credit policy in business cycle analysis. Handbook of monetary economics, 3(3), 547-599.

Ghironi, F. (2000). Alternative monetary rules for a small open economy: The case of Canada. Boston College Econ. Dept. WP, 466.

Goldberg, L. S. (2013). Banking globalization, transmission, and monetary policy autonomy. NBER Working Papers, No. w19497.

Ha, J., So, I. (2013). Influence of the Banks' Money Mediation Behavior on the Monetary Policy: A Study of Korean Case. Global Economic Review, 42(4), 396-424.

Hamilton, J. D. (1994). Time Series Analysis. Princeton University Press, Princeton, NJ.

Hofmann, B., Shim, I., and Shin, H.S. (2016). Soverign yields and the risk-taking channel of currency appreciation. BIS Working Papers, No. 538

Iacoviello, M. (2005). House prices, borrowing constraints, and monetary policy in the business cycle. American economic review, 739-764. 
Iacoviello, M. (2015). Financial business cycles. Review of Economic Dynamics, 18(1), 140163.

Kang, T. and Dao, T. (2012). International financial business cycles. manuscript

Kim, S. (2001). International transmission of U.S. monetary policy shocks: Evidence from VAR's. Journal of Monetary Economics, 48, 339372.

Kiyotaki, N., Moore, J. (1997). Credit cycles. The Journal of Political Economy, 105(2), 211-248.

Kalemli-Ozcan, S., Papaioannou, E., and Perri, F. (2013). Global banks and crisis transmission. Journal of International Economics, 89(2), 495-510.

Kollmann, R. (2002). Monetary policy rules in the open economy: effects on welfare and business cycles. Journal of Monetary Economics, 49(5), 989-1015.

Kollmann, R. (2013). Global banks, financial shocks, and international business cycles: Evidence from an estimated model. Journal of Money, Credit and Banking, 45(s2), 159-195.

Levine, R. (2004). Finance and growth: Theory and evidence. NBER Working Papers No. 10766

Lombardo, G., Vestin, D. (2008). Welfare implications of Calvo vs. Rotemberg-pricing assumptions. Economics Letters, 100(2), 275-279.

Matheson, T. (2010). Assessing the fit of small open economy DSGEs. Journal of Macroeconomics, 32(3), 906-920.

Morais, B., Peydro, J., and Ruiz, C. (2017). The International Bank Lending Channel of Monetary Policy Rates and QE: Credit Supply, Reach-for-Yield, and Real Eects. Journal of Finance, forthcoming

Obstfeld, M., and Rogoff, K. (1995). Exchange Rate Dynamics Redux. Journal of Political Economy, 624-660.

Obstfeld, M. (2014). Trilemmas and Tradeoffs: Living with Financial Globalization. manuscript 
Ostry, J., Ghosh, A., Habermeier, K., Laeven, L., Chamon, M., Qureshi, M., and Kokenyne, A. (2011). Managing Capital Infows: What Tools to Use? IMF Staff Discussion Note.

Passari, E., Rey, H. (2015). Financial Flows and the International Monetary System. The Economic Journal, 125(584), 675-698.

Rey, H. (2015). Dilemma not trilemma: the global nancial cycle and monetary policy independence. NBER Working Paper, No. w21162.

Rosenberg, C. B., Tirpak, M. (2008). Determinants of foreign currency borrowing in the new member states of the EU. IMF Working Papers, 1-24.

Rotemberg, J. J. (1982). Monopolistic price adjustment and aggregate output. The Review of Economic Studies, 49(4), 517-531.

Schmitt-Grohe, S., and M. Uribe. (2003). Closing Small Open Economy Models. Journal of International Economics, 61(1), 163-185.

Schnabl, P. (2012). The international transmission of bank liquidity shocks: Evidence from an emerging market. Journal of Finance, 67(3), 897-932.

Smets, F., and Wouters, R. (2007). Shocks and Frictions in US Business Cycles: A Bayesian DSGE Approach. The American Economic Review, 97(3), 586-606.

Tille, C. (2008). Financial integration and the wealth effect of exchange rate fluctuations. Journal of International Economics, 75(2), 283-294.

Van den Heuvel, S.J. (2008). The welfare cost of bank capital requirements. Journal of Monetary Economics, 55 (2), 298320.

Woodford, M. (2007). Globalization and Monetary Control. In: International Dimensions of Monetary Policy. NBER Chapters. National Bureau of Economic Research, 13-77. 


\section{Appendix}

\section{VAR Estimation Results of the Rest-of-the-World}

The structural shocks of a recursive VAR model of three variables $\left(\pi_{t}^{*}, \hat{y}_{t}^{*}\right.$, $\widehat{R_{t}^{*} I B}$; ordered as listed) are identified by using a standard Cholesky decomposition, as in Eq (A-1). I place the federal funds rate (FFR) last in the ordering as in Ghironi (2000), so that the output and inflation gap are restricted from simultaneously reacting to the interest rate shock, while FFR is allowed to react simultaneously to them.

$$
A X_{t}=\sum_{i=1}^{p} B_{i} X_{t-i}+\varepsilon_{t}
$$

where $X_{t}$ is a state vector, $A$ and $B_{i}\left(\forall_{i} \geq 1\right)$ are nonsingular coefficient matrices, and $\varepsilon_{t}$ is a structural disturbance vector.

Table A-1 reports the estimated coefficients. The results suggest that the signs and magnitude of the coefficients are in line with a generalized Taylor rule and Phillips curve.

Figure A-1 illustrates the responses of U.S GDP, inflation, and FFR to a 25bp increase in FFR. The output and inflation gap (deviation from the steady state) react with a lag of two or three quarters, and these results are in line with the literature. We can find that all variables return to their steady states over time. 


\section{1 \\ BOK Working Paper No. 2017-33}

Table A-1: Estimated Coefficients of U.S VAR

\begin{tabular}{|c|c|c|c|c|c|c|}
\hline & \multicolumn{2}{|c|}{$\widehat{\pi_{t}^{*}}$} & \multicolumn{2}{|c|}{$\widehat{y_{t}^{*}}$} & \multicolumn{2}{|c|}{$\widehat{R_{t}^{*}{ }^{* I B}}$} \\
\hline$\widehat{y_{t}^{*}}$ & & & & & 0.470 & $(0.221)$ \\
\hline$\widehat{\pi_{t}^{*}}$ & & & 0.183 & $(0.143)$ & 0.387 & $(0.145)$ \\
\hline$\widehat{\pi_{t-1}^{*}}$ & -0.088 & $(0.094)$ & -0.165 & $(0.143)$ & -0.426 & $(0.233)$ \\
\hline$\widehat{y_{t-1}^{*}}$ & 0.097 & $(0.058)$ & 0.970 & $(0.088)$ & -0.109 & $(0.143)$ \\
\hline$R_{t-1}^{\widehat{I B}^{*}}$ & 0.098 & $(0.041)$ & 0.093 & $(0.062)$ & 0.756 & $(0.101)$ \\
\hline$\widehat{\pi_{t-2}^{*}}$ & -0.158 & $(0.096)$ & 0.091 & $(0.146)$ & 0.371 & $(0.237)$ \\
\hline$\widehat{y_{t-2}^{*}}$ & 0.017 & $(0.057)$ & -0.061 & $(0.087)$ & -0.090 & $(0.142)$ \\
\hline$\widehat{R_{t-2} \widehat{I B}^{*}}$ & -0.111 & $(0.041)$ & -0.286 & $(0.062)$ & -0.036 & $(0.100)$ \\
\hline
\end{tabular}

Notes: The numbers in parenthesis are standard errors.

Figure A-1: Impulse Response to Contractionary U.S FFR (25bp)

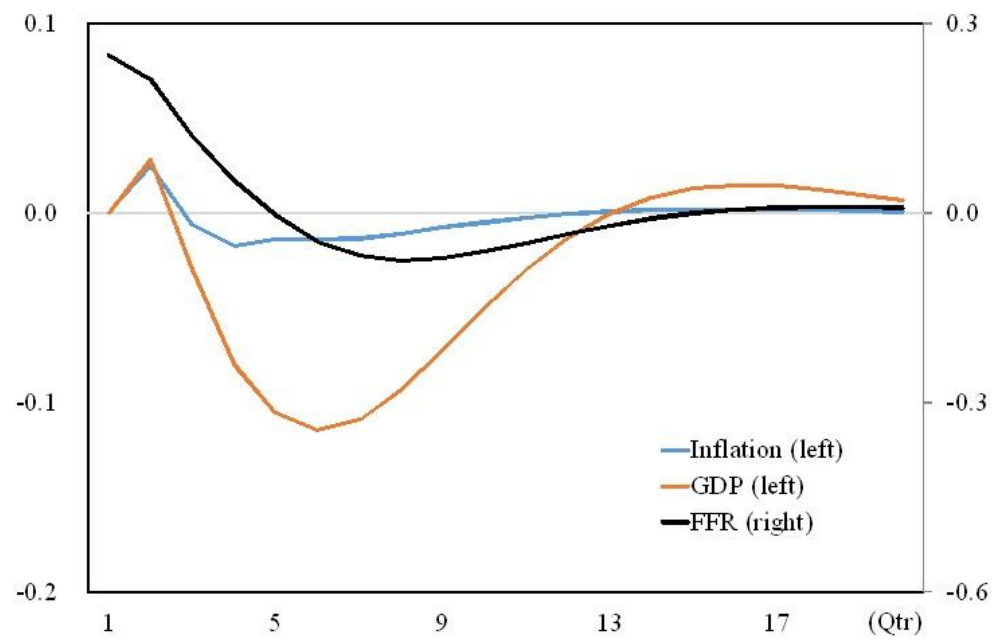

Notes: Horizontal axis: Quarters from the shock Vertical axis: Percentage deviation from steady state. 
2. Market Power in the Banking Sector and MP Transmission

The monopolistic power of banks is also an important source of the attenuation of MP transmission (see Gerali et al., 2010). I set up an alternative model (AM3) that blocks the bank attenuator channel. A comparison between AM 2 (green line) and AM3 (purple line) allows for capturing the bank attenuator effect. In response to a contractionary MP shock, market power in a banking industry induces financial intermediaries to adjust interest rates by a lower amount $(0.02 \% \mathrm{p}$ in deposit rate, $0.02 \% \mathrm{p}$ in loan rate to impatient households and $0.07 \% \mathrm{p}$ in loan rate to entrepreneurs), thereby decreasing the response of output by $0.07 \%$ p on average in the first year. 


\section{$<$ Abstract in Korean $>$}

\section{소규모 개방경제의 은행부문 개방이 통화정책 파급경로에 미치는 영향}

본고는 소규모 개방경제에서 은행부문 개방이 자국 및 해외 통화정책의 파급 경로에 미치는 영향에 대해 분석하였다. 분석을 위해 은행부문이 포함된 소규모 개방경제 DSGE 모형을 구축하였고, 은행부문 개방을 외화유동성 차입 및 외화대출 중개의 두 가지 유형으로 구분하여 고려하였다. 모형 분석 결과, 소규모 개방경제 에서 은행부문이 개방되는 경우 자국의 정책금리 조정이 국내 금융경제에 미치는 효과는 약화되는 것으로 나타났다. 반면, 은행부문 개방으로 인해 해외금리 충격이 국내 은행의 자금중개 과정에 미치는 영향은 강화되는 것으로 분석되었다.

핵심 주제어: 은행개방, 통화정책, DSGE 모형, 소규모 개방경제

JEL Classification: E32, E44, E52, E58, F36, F62

\footnotetext{
* 한국은행 국제국 국제금융부 국제금융연구팀 과장 (전 경제연구원 부연구위원, 전화: 02-759-5993, E-mail: insoh@bok.or.kr) 


\section{$\mathrm{BOK}$ 경제연구 발간목록}

한국은행 경제연구원에서는 Working Paper인 『BOK 경제연구』를 수시로 발간하고 있습니다. ${ }^{『} \mathrm{BOK}$ 경제연구』는 주요 경제 현상 및 정책 효과에 대한 직관적 설명 뿐 아니라 깊이 있는 이론 또는 실증 분석을 제공함으로써 엄밀한 논증에 초점을 두는 학술논문 형태의 연구이며 한국은행 직원 및 한국은행 연구용역사업의 연구 결과물이 수록되고 있습니다.

『BOK 경제연구』는 한국은행 경제연구원 홈페이지(http://imer.bok.or.kr)에서 다운로드하여 보실 수 있습니다.

제2014-1 Network Indicators for Monitoring Intraday Liquidity in BOK-Wire+

2 중소기업에 대한 신용정책 효과

3 경제충격 효과의 산업간 공행성 분석

4 서비스업 발전을 통한 내외수 균형성장 기대효과 및 리스크

5 Cross-country-heterogeneous and Time-varying Effects of Unconventional Monetary Policies in AEs on Portfolio Inflows to EMEs

6 인터넷뱅킹, 결제성예금 및 은행 수익성과의 관계 분석

7 Dissecting Foreign Bank Lending Behavior During the 2008-2009 Crisis

8 The Impact of Foreign Banks on Monetary Policy Transmission during the Global Financial Crisis of 2008-2009: Evidence from Korea

9 Welfare Cost of Business Cycles in Economies with Individual Consumption Risk

10 Investor Trading Behavior Around the Time of Geopolitical Risk Events: Evidence from South Korea

11 Imported-Inputs Channel of Exchange Rate Pass-Through: Evidence from Korean Firm-Level Pricing Survey
Seungjin Baek •

Kimmo Soram ki

Jaeho Yoon

정호성·임호성

황선웅·민성환 ·

신동현·김기호

김승원 · 황광명

Kyoungsoo Yoon •

Christophe Hurlin

이동규·전봉걸

Moon Jung Choi

Eva Gutierrez •

Maria Soledad Martinez Peria

Bang Nam Jeon $\cdot$

Hosung Lim $\cdot$ Ji Wu

Martin Ellison -

Thomas J. Sargent

Young Han Kim •

Hosung Jung

Jae Bin Ahn •

Chang-Gui Park 


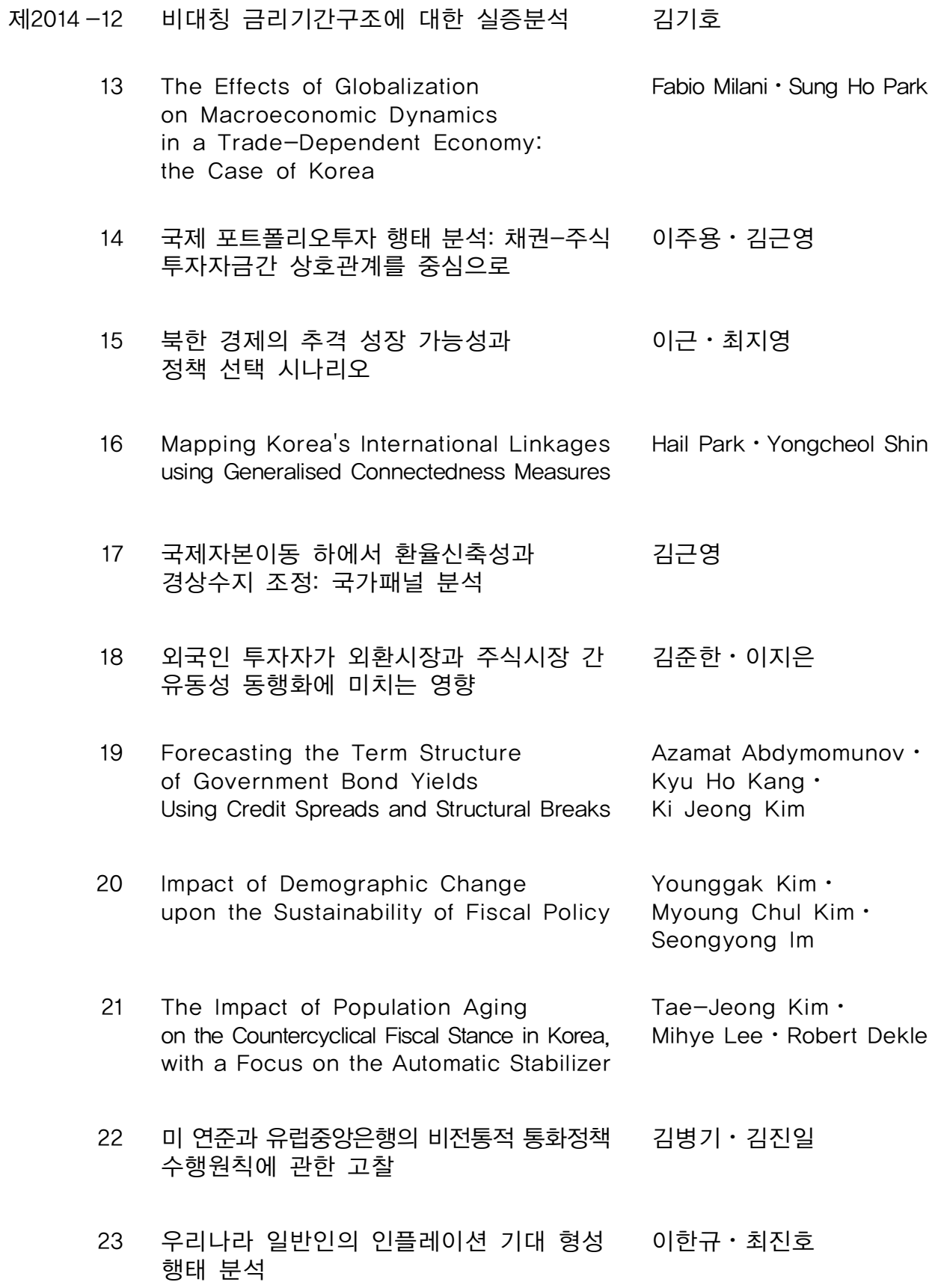

17 국제자본이동 하에서 환율신축성과 경상수지 조정: 국가패널 분석

18 외국인 투자자가 외환시장과 주식시장 간 유동성 동행화에 미치는 영향

19 Forecasting the Term Structure of Government Bond Yields Using Credit Spreads and Structural Breaks

이주용·김근영

이근 · 최지영

Hail Park $\cdot$ Yongcheol Shin

김근영

김준한 $\cdot$ 이지은

Azamat Abdymomunov • Kyu Ho Kang •

Ki Jeong Kim

20 Impact of Demographic Change upon the Sustainability of Fiscal Policy

21 The Impact of Population Aging on the Countercyclical Fiscal Stance in Korea, Younggak Kim • Myoung Chul Kim • Seongyong Im

Tae-Jeong Kim • with a Focus on the Automatic Stabilizer

Mihye Lee $\cdot$ Robert Dekle

22 미 연준과 유럽중앙은행의 비전통적 통화정책 수행원칙에 관한 고찰

23 우리나라 일반인의 인플레이션 기대 형성 행태 분석

김병기· 김진일

이한규・최진호 


\section{제2014-24 Nonlinearity in Nexus between \\ Working Hours and Productivity \\ 25 Strategies for Reforming Korea's Labor Market to Foster Growth}

26 글로벌 금융위기 이후 성장잠재력 확충: 2014 한국은행 국제컨퍼런스 결과보고서

27 인구구조 변화가 경제성장률에 미치는 영향: 자본이동의 역할에 대한 논의를 중심으로

28 Safe Assets

29 확장된 실업지표를 이용한 우리나라 노동시장에서의 이력현상 분석

30 Entropy of Global Financial Linkages

31 International Currencies Past, Present and Future: Two Views from Economic History

32 금융체제 이행 및 통합 사례:

남북한 금융통합에 대한 시사점

33 Measuring Price-Level Uncertainty and Instability in the U.S., 1850-2012

34 고용보호제도가 노동시장 이원화 및 노동생산성에 미치는 영향

35 해외충격시 외화예금의 역할 : 주요 신흥국 신용스프레드에 미치는 영향을 중심으로

36 실업률을 고려한 최적 통화정책 분석

37 우리나라 무역거래의 결제통화 결정요인 분석

Global Liquidity Transmission to Emerging Market Economies, and Their Policy Responses
Dongyeol Lee $\cdot$

Hyunjoon Lim

Mai Dao · Davide Furceri • Jisoo Hwang .

Meeyeon Kim .

Tae-Jeong Kim

한국은행 경제연구원

손종칠

Robert J. Barro

김현학 · 황광명

Daeyup Lee

Barry Eichengreen

김병연

Timothy Cogley •

Thomas J. Sargent

김승원

정호성· 우준명

김인수 · 이명수

황광명·김경민·

노충식·김미진

Woon Gyu Choi ·

Taesu Kang •

Geun-Young Kim •

Byongju Lee 


\begin{tabular}{|c|c|c|}
\hline 제2015 -1 & $\begin{array}{l}\text { 글로벌 금융위기 이후 주요국 } \\
\text { 통화정책 운영체계의 변화 }\end{array}$ & 김병기· 김인수 \\
\hline 2 & $\begin{array}{l}\text { 미국 장기시장금리 변동이 우리나라 } \\
\text { 금리기간구조에 미치는 영향 분석 및 } \\
\text { 정책적 시사점 }\end{array}$ & 강규호·오형석 \\
\hline 3 & $\begin{array}{l}\text { 직간접 무역연계성을 통한 해외충격의 } \\
\text { 우리나라 수출입 파급효과 분석 }\end{array}$ & 최문정· 김근영 \\
\hline 4 & 통화정책 효과의 지역적 차이 & 김기호 \\
\hline 5 & $\begin{array}{l}\text { 수입중간재의 비용효과를 고려한 } \\
\text { 환율변동과 수출가격 간의 관계 }\end{array}$ & 김경민 \\
\hline 6 & $\begin{array}{l}\text { 중앙은행의 정책금리 발표가 } \\
\text { 주식시장 유동성에 미치는 영향 }\end{array}$ & 이지은 \\
\hline 7 & $\begin{array}{l}\text { 은행 건전성지표의 변동요인과 } \\
\text { 거시건전성 규제의 영향 }\end{array}$ & 강종구 \\
\hline 8 & $\begin{array}{l}\text { Price Discovery and Foreign Participation } \\
\text { in The Republic of Korea's } \\
\text { Government Bond Futures } \\
\text { and Cash Markets }\end{array}$ & $\begin{array}{l}\text { Jaehun Choi } \cdot \text { Hosung Lim } \cdot \\
\text { Rogelio Jr. Mercado } \\
\text { Cyn-Young Park }\end{array}$ \\
\hline 9 & $\begin{array}{l}\text { 규제가 노동생산성에 미치는 영향: } \\
\text { 한국의 산업패널 자료를 이용한 실증분석 }\end{array}$ & 이동렬·최종일·이종한 \\
\hline 10 & $\begin{array}{l}\text { 인구 고령화와 정년연장 연구 } \\
\text { (세대 간 중첩모형(OLG)을 이용한 정량 분석) }\end{array}$ & 홍재화·강태수 \\
\hline 11 & $\begin{array}{l}\text { 예측조합 및 밀도함수에 의한 } \\
\text { 소비자물가 상승률 전망 }\end{array}$ & 김현학 \\
\hline 12 & 인플레이션 동학과 통화정책 & 우준명 \\
\hline 13 & $\begin{array}{l}\text { Failure Risk and the Cross-Section } \\
\text { of Hedge Fund Returns }\end{array}$ & Jung-Min Kim \\
\hline 14 & Global Liquidity and Commodity Prices & $\begin{array}{l}\text { Hyunju Kang } \\
\text { Bok-Keun Yu. } \\
\text { Jongmin Yu }\end{array}$ \\
\hline 15 & $\begin{array}{l}\text { Foreign Ownership, Legal System } \\
\text { and Stock Market Liquidity }\end{array}$ & Jieun Lee $\cdot$ Kee $\mathrm{H}$. Chung \\
\hline
\end{tabular}




\begin{tabular}{|c|c|c|}
\hline 제2015 -16 & $\begin{array}{l}\text { 바젤 II 은행 경기대응완충자본 규제의 } \\
\text { 기준지표에 대한 연구 }\end{array}$ & 서현덕·이정연 \\
\hline 17 & 우리나라 대출 수요와 공급의 변동요인 분석 & 강종구·임호성 \\
\hline 18 & 북한 인구구조의 변화 추이와 시사점 & 최지영 \\
\hline 19 & $\begin{array}{l}\text { Entry of Non-financial Firms and Competition } \\
\text { in the Retail Payments Market }\end{array}$ & Jooyong Jun \\
\hline 20 & $\begin{array}{l}\text { Monetary Policy Regime Change } \\
\text { and Regional Inflation Dynamics: } \\
\text { Looking through the Lens of } \\
\text { Sector-Level Data for Korea }\end{array}$ & $\begin{array}{l}\text { Chi-Young Choi } \\
\text { Joo Yong Lee } \\
\text { Roisin O'Sullivan }\end{array}$ \\
\hline 21 & $\begin{array}{l}\text { Costs of Foreign Capital Flows } \\
\text { in Emerging Market Economies: } \\
\text { Unexpected Economic Growth } \\
\text { and Increased Financial Market Volatility }\end{array}$ & $\begin{array}{l}\text { Kyoungsoo Yoon } \\
\text { Jayoung Kim }\end{array}$ \\
\hline 22 & $\begin{array}{l}\text { 글로벌 금리 정상화와 통화정책 과제: } \\
\text { 2015년 한국은행 국제컨퍼런스 결과보고서 }\end{array}$ & 한국은행 경제연구원 \\
\hline 23 & $\begin{array}{l}\text { The Effects of Global Liquidity } \\
\text { on Global Imbalances }\end{array}$ & $\begin{array}{l}\text { Marie-Louise DJIGBENOU-KRE } \\
\text { Hail Park }\end{array}$ \\
\hline 24 & 실물경기를 고려한 내재 유동성 측정 & 우준명·이지은 \\
\hline 25 & Deflation and Monetary Policy & Barry Eichengreen \\
\hline 26 & $\begin{array}{l}\text { Macroeconomic Shocks } \\
\text { and Dynamics of Labor Markets in Korea }\end{array}$ & $\begin{array}{l}\text { Tae Bong Kim } \cdot \\
\text { Hangyu Lee }\end{array}$ \\
\hline 27 & $\begin{array}{l}\text { Reference Rates and Monetary Policy } \\
\text { Effectiveness in Korea }\end{array}$ & $\begin{array}{l}\text { Heung Soon Jung } \\
\text { Dong Jin Lee } \\
\text { Tae Hyo Gwon. } \\
\text { Se Jin Yun }\end{array}$ \\
\hline 28 & Energy Efficiency and Firm Growth & $\begin{array}{l}\text { Bongseok Choi } \\
\text { Wooyoung Park } \\
\text { Bok-Keun } \mathrm{Yu}\end{array}$ \\
\hline 29 & $\begin{array}{l}\text { An Analysis of Trade Patterns } \\
\text { in East Asia and the Effects of } \\
\text { the Real Exchange Rate Movements }\end{array}$ & $\begin{array}{l}\text { Moon Jung Choi } \\
\text { Geun-Young Kim } \\
\text { Joo Yong Lee }\end{array}$ \\
\hline 30 & $\begin{array}{l}\text { Forecasting Financial Stress Indices in } \\
\text { Korea: A Factor Model Approach }\end{array}$ & $\begin{array}{l}\text { Hyeongwoo Kim } \\
\text { Hyun Hak Kim } \\
\text { Wen Shi }\end{array}$ \\
\hline
\end{tabular}




\begin{tabular}{|c|c|c|}
\hline 제2016 -1 & $\begin{array}{l}\text { The Spillover Effects of U.S. Monetary } \\
\text { Policy on Emerging Market Economies: } \\
\text { Breaks, Asymmetries and Fundamentals }\end{array}$ & $\begin{array}{l}\text { Geun-Young Kim } \cdot \\
\text { Hail Park } \\
\text { Peter Tillmann }\end{array}$ \\
\hline 2 & $\begin{array}{l}\text { Pass-Through of Imported Input Prices } \\
\text { to Domestic Producer Prices: Evidence } \\
\text { from Sector-Level Data }\end{array}$ & $\begin{array}{l}\text { JaeBin Ahn } \\
\text { Chang-Gui Park } \\
\text { Chanho Park }\end{array}$ \\
\hline 3 & $\begin{array}{l}\text { Spillovers from U.S. Unconventional } \\
\text { Monetary Policy and Its Normalization } \\
\text { to Emerging Markets: A Capital Flow } \\
\text { Perspective }\end{array}$ & $\begin{array}{l}\text { Sangwon Suh } \\
\text { Byung-Soo Koo }\end{array}$ \\
\hline 4 & $\begin{array}{l}\text { Stock Returns and Mutual Fund Flows } \\
\text { in the Korean Financial Market: } \\
\text { A System Approach }\end{array}$ & $\begin{array}{l}\text { Jaebeom Kim } \\
\text { Jung-Min Kim }\end{array}$ \\
\hline 5 & $\begin{array}{l}\text { 정책금리 변동이 성별·세대별 고용률에 } \\
\text { 미치는 영향 }\end{array}$ & 정성엽 \\
\hline 6 & $\begin{array}{l}\text { From Firm-level Imports to } \\
\text { Aggregate Productivity: Evidence } \\
\text { from Korean Manufacturing Firms Data }\end{array}$ & $\begin{array}{l}\text { JaeBin Ahn } \\
\text { Moon Jung Choi }\end{array}$ \\
\hline 7 & $\begin{array}{l}\text { 자유무역협정(FTA)이 한국 기업의 } \\
\text { 기업내 무역에 미친 효과 }\end{array}$ & 전봉걸 - 김은숙 - 이주용 \\
\hline 8 & $\begin{array}{l}\text { The Relation Between Monetary and } \\
\text { Macroprudential Policy }\end{array}$ & Jong Ku Kang \\
\hline 9 & $\begin{array}{l}\text { 조세피난처 투자자가 투자 기업 및 주식 } \\
\text { 시장에 미치는 영향 }\end{array}$ & 정호성·김순호 \\
\hline 10 & $\begin{array}{l}\text { 주택실거래 자료를 이용한 주택부문 거시 } \\
\text { 건전성 정책 효과 분석 }\end{array}$ & 정호성·이지은 \\
\hline 11 & $\begin{array}{l}\text { Does Intra-Regional Trade Matter in } \\
\text { Regional Stock Markets?: New Evidence } \\
\text { from Asia-Pacific Region }\end{array}$ & $\begin{array}{l}\text { Sei-Wan Kim } \cdot \\
\text { Moon Jung Choi }\end{array}$ \\
\hline 12 & $\begin{array}{l}\text { Liability, Information, and Anti-fraud } \\
\text { Investment in a Layered Retail } \\
\text { Payment Structure }\end{array}$ & $\begin{array}{l}\text { Kyoung-Soo Yoon } \\
\text { Jooyong Jun }\end{array}$ \\
\hline 13 & $\begin{array}{l}\text { Testing the Labor Market Dualism in } \\
\text { Korea }\end{array}$ & $\begin{array}{l}\text { Sungyup Chung } \\
\text { Sunyoung Jung }\end{array}$ \\
\hline 14 & $\begin{array}{l}\text { 북한 이중경제 사회계정행렬 추정을 통한 } \\
\text { 비공식부문 분석 }\end{array}$ & 최지영 \\
\hline
\end{tabular}




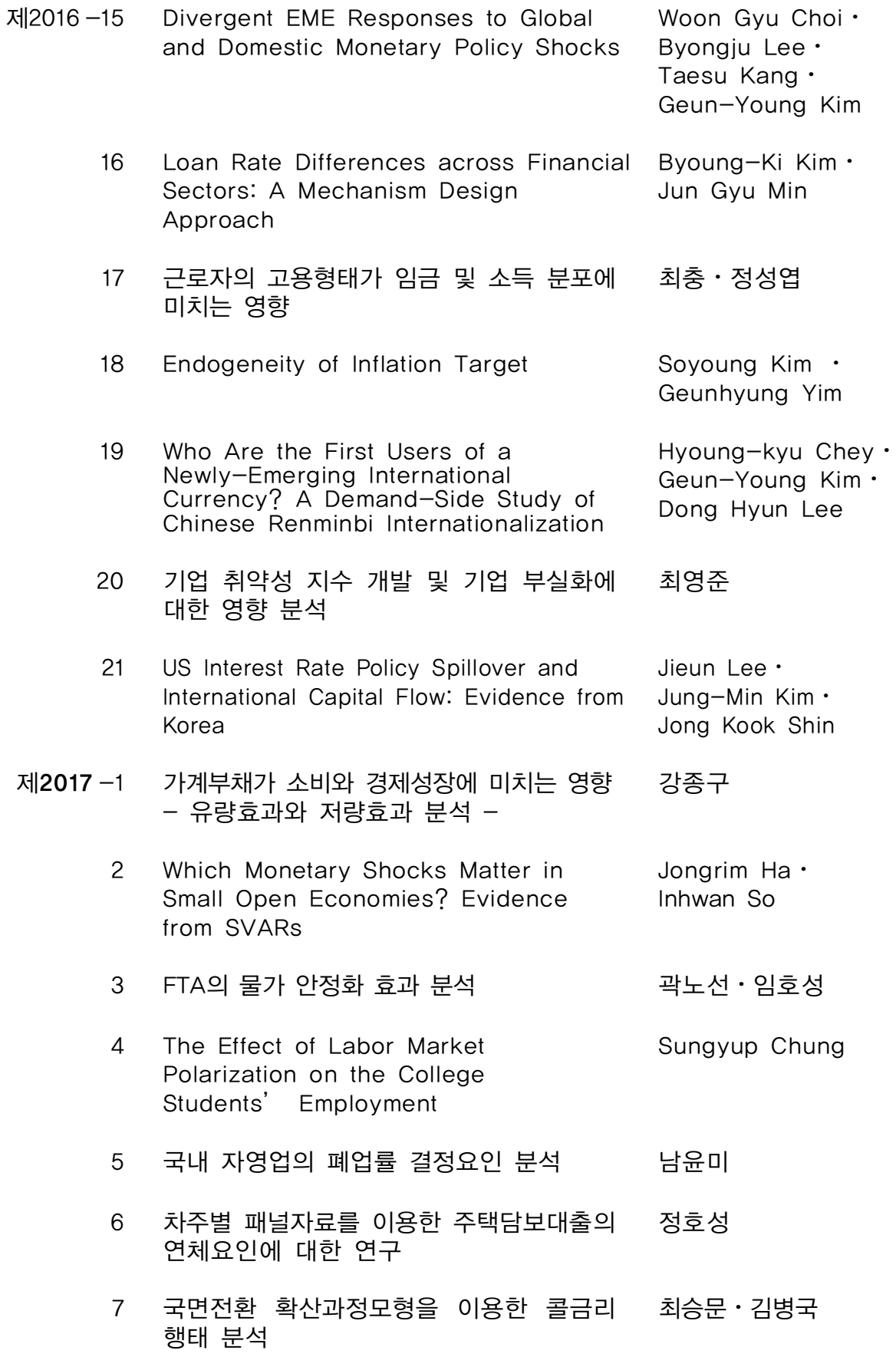

2 Which Monetary Shocks Matter in Small Open Economies? Evidence from SVARs

3 FTA의 물가 안정화 효과 분석

곽노선·임호성

4 The Effect of Labor Market

Sungyup Chung Polarization on the College Jongrim $\mathrm{Ha} \cdot$ Inhwan So Students' Employment

5 국내 자영업의 폐업률 결정요인 분석 남윤미

6 차주별 패널자료를 이용한 주택담보대출의 정호성 연체요인에 대한 연구

7 국면전환 확산과정모형을 이용한 콜금리 최승문·김병국 행태 분석 


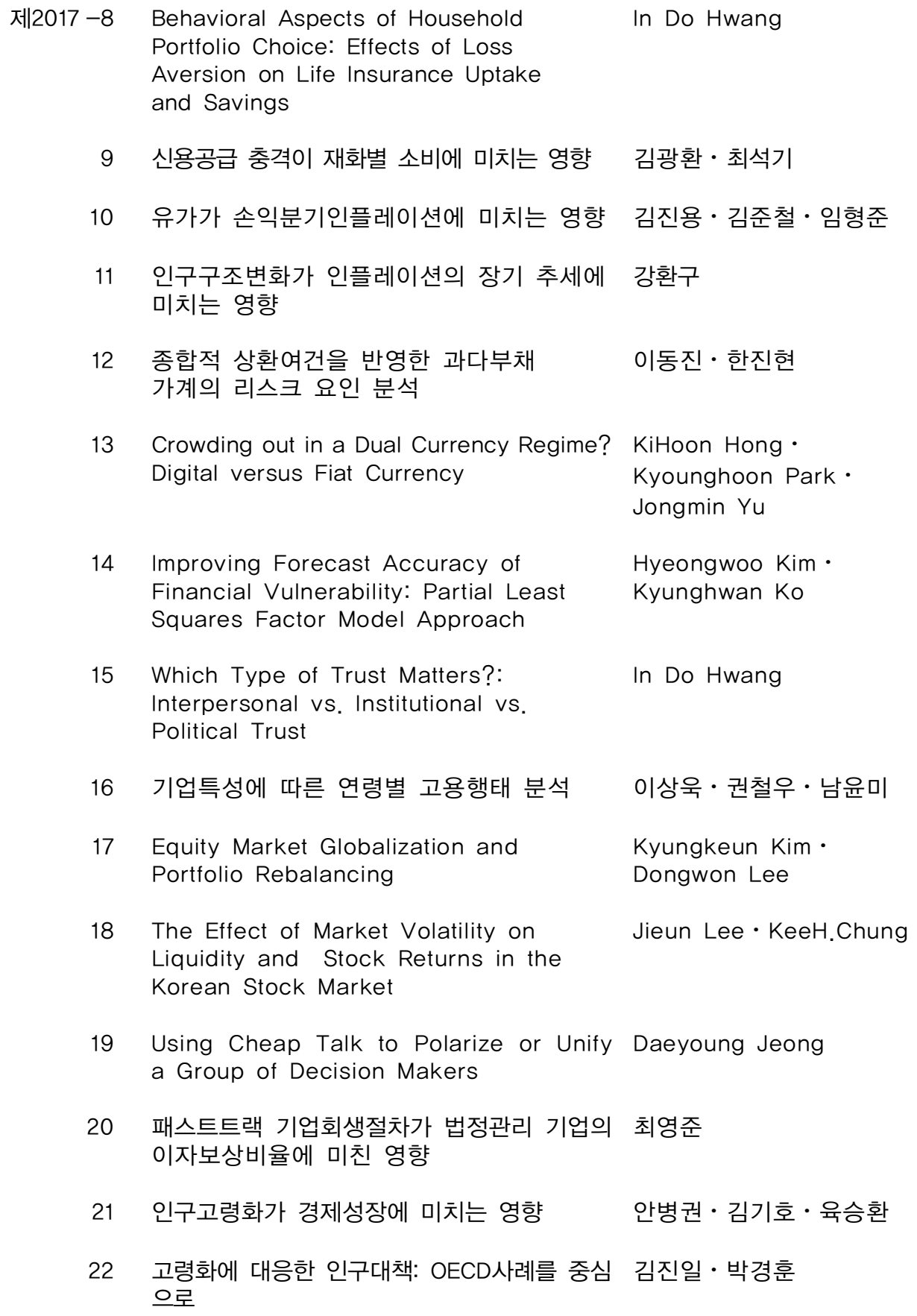




\begin{tabular}{|c|c|c|}
\hline 제2017 -23 & 인구구조변화와 경상수지 & 김경근 · 김소영 \\
\hline 24 & 통일과 고령화 & 최지영 \\
\hline 25 & 인구고령화가 주택시장에 미치는 영향 & $\begin{array}{l}\text { 오강현·김솔·윤재준· } \\
\text { 안상기·권동휘 }\end{array}$ \\
\hline 26 & 고령화가 대외투자에 미치는 영향 & 임진수·김영래 \\
\hline 27 & $\begin{array}{l}\text { 인구고령화가 가계의 자산 및 부채에 } \\
\text { 미치는 영향 }\end{array}$ & 조세형·이용민·김정훈 \\
\hline 28 & $\begin{array}{l}\text { 인구고령화에 따른 우리나라 산업구조 } \\
\text { 변화 }\end{array}$ & 강종구 \\
\hline 29 & 인구구조 변화와 재정 & 송호신·허준영 \\
\hline 30 & 인구고령화가 노동수급에 미치는 영향 & 이철희·이지은 \\
\hline 31 & 인구 고령화가 금융산업에 미치는 영향 & $\begin{array}{l}\text { 윤경수·차재훈·박소희· } \\
\text { 강선영 }\end{array}$ \\
\hline 32 & 금리와 은행 수익성 간의 관계 분석 & 한재준·소인환 \\
\hline 33 & $\begin{array}{l}\text { Bank Globalization and Monetary } \\
\text { Policy Transmission in Small Open } \\
\text { Economies }\end{array}$ & Inhwan So \\
\hline
\end{tabular}

